\title{
Estudio sobre la composición de imagen cinematográfica: encuadre, luz y color como elementos expresivos en la obra de Roger Deakins
}

\section{Study on the cinematographic image composition: frame, light, and colour as expressive elements in Roger Deakin's work}

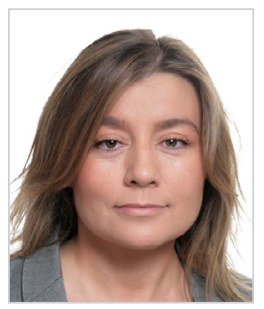

Ana Isabel Cea Navas. Doctora en Comunicación Audiovisual (Universidad de Valladolid). Master en $H^{\mathrm{a}}$ y Estética de la Cinematografía (Cátedra de Cine, UVA). Experta en el cortometraje de ficción español y sus temáticas sociales (línea de investigación desde 99). Autora y coautora de diferentes publicaciones dedicadas al relato breve cinematográfico. En 2004 comienza su actividad docente en diferentes universidades (actualmente trabaja como profesora asociada en Universidad de Valladolid), impartiendo materias sobre Comunicación Audiovisual y/o cinematográfica. Ha unido el ámbito académico con el profesional (industria del cine, especialmente en el sector del formato corto). Ha guionizado, dirigido y coproducido el largometraje documental Cortos infinitos (2017).

Universidad de Valladolid, España

anaisabel.cea@uva.es

ORCID: 0000-0003-3859-0221

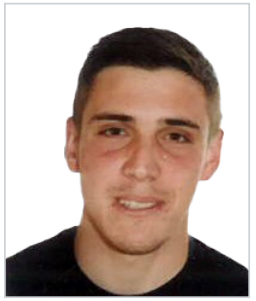

Sergio García Rubio. Graduado en Periodismo por la Universidad de Valladolid. Máster en Nuevos Medios Interactivos y Periodismo Multimedia por la Universidad de Granada que culmina con su Trabajo Fin de Máster titulado: Análisis y uso del mcGuffin en la filmografía de Quentin Tarantino, un estudio que le conduce a iniciar su trayectoria académica y de investigación. Su vida laboral se ha centrado principalmente en labores periodísticas realizadas en diferentes ámbitos: medios de comunicación: ABC Castilla y León; eventos de la industria del cine: Semana Internacional de Cine de Valladolid (SEMINCI) y en organismos institucionales: Diputación de Granada. Universidad de Granada, España

sergiogr97@correo.ugr.es

ORCID: 0000-0002-5579-582X

Recibido: 11/05/2020 - Aceptado: 17/11/2020

\section{Resumen:}

El cine se ha convertido en uno de los medios más influyentes en la sociedad desde sus orígenes en el siglo XIX por diversos motivos: su carácter artístico-estético, técnico, narrativo-comunicativo, etc. En este sentido, el Séptimo Arte se ha situado como producto creativo e industrial fundamental de la cultura que ha ido evolucionando a lo largo de los años. Teniendo en cuenta el desarrollo y valor de la cinematografía, el presente estudio intenta abordar la manera en la que los encuadres, la luz y el color de las imágenes que conforman un filme sirven como elementos expresivos. Para
Received: 11/05/2020 - Accepted: 17/11/2020

\section{Abstract:}

Cinema has become one of the most influential elements in the society since its origins in the $19^{\text {th }}$ century, for various reasons: its artistic-aesthetic, narrative-communicative, technical, etc. In this sense, the Seventh Art has become a fundamental creative and industrial product of the culture that has evolved over the years. Taking into account the development and value of cinematography, this study attempts to address the way in which the frames, light and color of the images that make up a film serve as expressive elements. To do this, this research analyzes the film composition

Cómo citar este artículo:

Cea Navas, A. I.; García Rubio, S. (2020). Estudio sobre la composición de imagen cinematográfica: encuadre, luz y color como elementos expresivos en la obra de Roger Deakins. Doxa Comunicación, 31, pp. 207-238.

https://doi.org/10.31921/doxacom.n31a10 
ello, esta investigación analiza el trabajo de composición cinematográfica de Roger Deakins en cuatro de sus obras: Fargo, El hombre que nunca estuvo allí, Sicario y Blade Runner 2049. Asimismo, planteamos también si el camarógrafo tiene un estilo definido. Paralelamente, pretendemos poner en relieve el oficio del director de fotografía, como figura encargada de la construcción del cuadro del relato fílmico.

Palabras clave:

Roger Deakins; director de fotografía; luz-iluminación; color; encuadre.

\section{Introducción}

Desde sus orígenes a finales del siglo XIX, el cine se ha convertido en un instrumento de comunicación con gran capacidad de influencia. En un primer momento, se empezó a estudiar la funcionalidad de las imágenes en movimiento y su influjo en la educación y alfabetización de la sociedad. Algunas escuelas, como la formalista rusa, ya investigaron sobre la percepción visual del ser humano y la forma en la que con ella ya no sería necesario entender el lenguaje escrito o hablado, la comprensión de los mensajes del cine estaba garantizada (Romaguera y Alsina, 1989). Se puede hablar del Séptimo Arte como un medio de expresión, de comunicación, que ahonda en las emociones del espectador. Será éste quien forme el último eslabón del relato cinematográfico, que no terminará hasta que sea aceptado, consumido, por el receptor (Guerín, 2004). Esto hace que la subjetividad del público sea uno de los elementos más importantes sobre los que se puede trabajar en un filme, algo a lo que ayuda en gran medida la praxis de fotografía o la cinematografía de una película. Por todo ello, esta investigación analiza elementos expresivos en la composición de las imágenes cinematográficas: encuadre, luz y color. En el intento de mostrar esta facultad comunicativa, expresiva, se ha pensado en estudiar el trabajo del director de fotografía Roger Deakins, centrado en los largometrajes: Fargo (Joel Coen, 1996), El hombre que nunca estuvo allí (The Man Who Wasn't There, Joel y Ethan Coen, 2001), Sicario (Denis Villeneuve, 2015), y Blade Runner 2049 (Denis Villeneuve, 2017).

El estudio de las obras seleccionadas nos permitirá comprender la labor que Deakins realiza, su función expresiva y la posibilidad de descubrir los rasgos que lo caracterizan. Nos inclinamos a pensar que sí tiene una impronta personal, una huella que le identifica e intentaremos constatarlo a lo largo de las siguientes páginas, pese a que él en una de sus entrevistas duda acerca de tener un carácter propio en su modo de crear y expone que espera poseer un estilo que funcione para cada proyecto ${ }^{1}$.

\subsection{Dirección de fotografía en el cine: un proceso técnico-creativo}

El apartado fotográfico de una película es uno de los más importantes dentro del Séptimo Arte, un aspecto que construye la imagen de la cinta y que marca su seña de identidad y su estética. No obstante, este ejercicio sigue siendo uno de los

1 Disponible en: https://n9.cl/dl4f 
menos conocidos de todo lo que engloba un filme, relegado a un segundo plano. Así, decidimos estudiar el trabajo de un director de fotografía para valorar las técnicas que utiliza y entender el cine como medio expresivo, por tanto, comunicativo, que permite transmitir emociones mediante la composición de sus imágenes. A pesar de ser uno de los aspectos más significativos dentro la disciplina cinematográfica, este proceso técnico-creativo, sigue siendo una tarea poco visible y escasamente reconocida respecto a su trascendencia en el oficio del cine. En su favor, actualmente, se han dado hechos en los que se demuestra que la fotografía fílmica cada vez está adquiriendo una mayor relevancia. Por ejemplo, en la XCI Edición de los Premios Oscar, tras entregar el galardón a esta categoría durante la pausa publicitaria, los mexicanos Guillermo del Toro y Alfonso Cuarón, salieron en defensa de la fotografía. El primero consideró a la dirección de fotografía como una representación del cine en sí mismo: "No pretendo sugerir qué categorías excluir durante la gala de los Oscar pero las de fotografía y montaje son el corazón de nuestro oficio". Cuarón, defendió la esencialidad de la fotografía en el cine a través de su cuenta de Twitter ${ }^{3}$.

\subsubsection{Funciones del director de fotografía}

La importancia de director de fotografía en todo film es capital, como se aprecia en Cortés-Selva (2014).

El camarógrafo se encarga del diseño de la imagen, hace que sea visible y se construya de manera adecuada. Interviene en todas las fases del proceso creativo del film:

- Preproducción: visita las localizaciones, redacta el informe (descripción del lugar: dimensiones, tomas eléctricas, aspectos del decorado, etc.) e interpreta los propósitos del guionista o del director en términos de luz para transformarlos en reales a través de la cámara. Lo más complicado es recrear las ideas del otro (Llinás, 1989), el guion no revela cuál es el estilo fotográfico de un film: el director de fotografía marcará el clima que requiere la imagen de la cinta (Aronovich, 1997).

- Producción: compone el encuadre, elige la posición de los propios personajes en la escena (siempre en consenso con el director de la película), crea la iluminación idónea (clasificación, posición de cámara y focos, intensidad, contrastes, efectos...) con aquello que se pretende describir o trasmitir, elige la óptica (ambientación lumínica acorde al guion), se responsabiliza del equipo de cámara, tanto de los recursos técnicos como humanos.

- Postproducción: supervisa el montaje, evalúa el etalonaje (corrección de color, contraste, luminosidad), comprueba efectos.

El director de fotografía también es autor (Cortés-Selva, 2020). Conjuga a la perfección los parámetros esenciales para que una imagen sea visible: luz, color y composición. Posee altas capacidades técnicas y artísticas, además de dominar por completo la articulación del lenguaje audiovisual. La calidad técnico-estética de la película recae en la dirección de fotografía. Las decisiones que se tomen sobre ella incurrirán en el resultado expresivo, comunicativo y, consecuentemente, en las emociones del espectador. Las acciones del cinematógrafo influyen en el éxito de la película (Crespo, 2013).

\footnotetext{
2 https://n9.cl/nj14
}

3 https://n9.cl/kvdkg 


\subsection{Apuntes sobre Roger Deakins}

La decisión de ahondar en la creación de Roger Deakins viene motivada, en un primer término, por el reconocimiento de su trayectoria. Es una de las personas más representativas del mundo de la fotografía en el cine, capaz de conseguir resultados y composiciones complejas, como pueden ser las imágenes decoloradas y añejas que se adecuan al universo gris, desesperanzado y claustrofóbico que Orwell describía en sus páginas (Santos-Aparicio, 2019). Además, debemos ensalzar su obra: 80 títulos $^{4}$, hasta el momento (5 televisivos y 75 cinematográficos) y su modo de concebirla. Estos factores han hecho que decidamos escoger este director de fotografía para analizar su trabajo a través de los largometrajes elegidos.

\subsection{Visiones, perspectivas sobre la composición en el cine}

Los estudios centrados exclusivamente en la obra de Roger Deakins en el campo académico son escasos: el artículo de Viñolo y Suarez (2018), aunque centrado en animación (técnica 2D); los diversos textos de la revista American Cinematographer: The International Journal of Film \& Digital Production Techniques, donde se referencia el trabajo de dirección de fotografía de Deakins como un ejemplo más en el cine, pero no da protagonismo al camarógrafo.

Respecto a las publicaciones especializadas en cine, con carácter divulgativo, cabe citar también, Cahiers du cinema España, actual, Caimán Cuadernos de Cine, que inciden en la faceta del cinematógrafo o dedican secciones en las que se incluyen entrevistas al propio Deakins.

Por todo ello, consideramos que este proyecto contribuye a paliar ciertas carencias en torno a la labor de dirección de fotografía, profundizando en sus posibilidades expresivas, enunciativas. Consideramos que el estudio sobre la tarea de dirección de fotografía de Deakins supone un ensayo de valor para comprender este potencial expresivo en el cine, presentando un campo novedoso en el ámbito de las ciencias sociales y en los estudios de comunicación.

A lo largo del proceso de documentación se han revisado textos dedicados específicamente al oficio de dirección de fotografía y el tratamiento visual de imágenes cinematográficas, como los escritos por Tolan (1941), Llinás, (1989), Aronovich, (1997), Crespo, (2013).

Necesarios son los postulados del maestro de la luz, Almendros (1980), los de Loiseleux (2005) y, más recientemente, las investigaciones de Cortés-Selva $(2014 ; 2019 ; 2020)$.

Asimismo, se han tenido en cuenta las reflexiones sobre la expresividad del color realizadas por González-Requena (1989) quien, a su vez, alude a Turner.

Por otra parte, para poder conformar el análisis sobre los elementos expresivos analizados en la obra de Deakins hemos recurrido a las teorías de Salt (2006) y Brown (2008). En el caso del estudio de los encuadres utilizados abordamos la observación del color en base a los postulados de Heller (2008), y en referencia al tratamiento de la iluminación, hemos seguido las aportaciones de Gutiérrez-San Miguel (2006; 2020).

4 Disponible en: https://www.imdb.com/name/nm0005683/ 


\subsection{Objetivos e hipótesis}

La investigación parte de un objetivo general: examinar la composición de imagen cinematográfica en la obra del director de fotografía Roger Deakins.

El estudio también incluye objetivos específicos que derivan del principal:

1. Observar y analizar el encuadre, la luz y el color como elementos expresivos de la construcción del relato cinematográfico creado por Roger Deakins, en las películas seleccionadas.

2. Apreciar similitudes entre los trabajos realizados en las diferentes cintas.

3. Advertir qué técnicas predominan y su frecuencia de uso. Así poder comprobar la existencia de una impronta personal en el trabajo de este director de fotografía.

Tras haber establecido los objetivos, planteamos la hipótesis de partida:

La labor de dirección de fotografía de Roger Deakins es crucial para el significado de los filmes en los que interviene. Los recursos técnico-artísticos, que emplea -encuadre, luz y color- marcan expresivamente su obra.

La composición de imágenes en las obras de Roger Deakins, caracterizada por la recurrencia de algunos de estos elementos técnico-artísticos (ejemplo: empleo en mayor medida de primeros planos), nos conduce a pensar que este director de fotografía ha adquirido a lo largo de su trayectoria un estilo propio.

\section{Método}

Examinamos el ejercicio de dirección fotográfica de Deakins a través de un método mixto, empleando técnicas cualitativas y cuantitativas para "utilizar las fortalezas de ambos tipos de indagación, combinándolas y tratando de minimizar sus debilidades potenciales" (Hernández-Sampieri, 2014: 532). Arrancamos la investigación con la hipótesis de partida. Para intentar verificarla desarrollamos una exploración secuencial siguiendo el enfoque de Casasempere (2020):

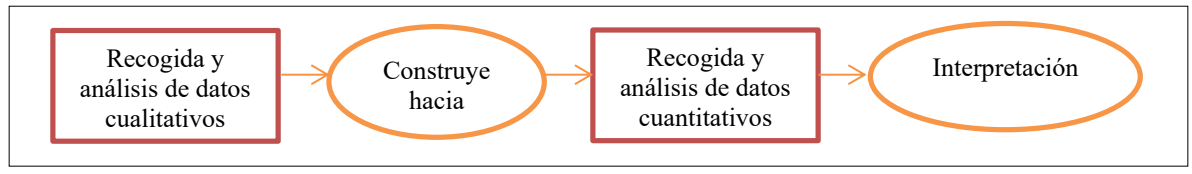

Fuente: elaboración propia. Basado en el esquema de Casasempere (2020)

La técnica de análisis de contenido cualitativo nos permite interpretar los textos filmados. Basada en la lectura visual como instrumento de recogida de información (Andreu y Pérez, 2006), se estructura en diversas fases: (a) observación del objeto de estudio -visionado de las obras seleccionadas-; (b) recogida de datos; (c) análisis de los largometrajes; (d) identificación de la frecuencia en el uso de las variables de investigación; (e) codificación; (f) obtención de resultados e interpretación; (g) deducción de conclusiones.

Los procedimientos cuantitativos se aplican para la medición de la frecuencia de uso de las tipologías de la primera categoría analizada (los encuadres). 


\subsection{La muestra}

La elección de la muestra, los largometrajes seleccionados, atiende a diversas razones: analizar obras realizadas en diversas épocas (finales del siglo XX, principios del XXI y década actual) y por directores distintos, seleccionando dos narraciones de cada uno de ellos. Respecto a Fargo, la justificación radica en que esta obra marca la consolidación de la relación laboral con los hermanos Coen ${ }^{5}$, los dos creadores con los que Deakins más ha trabajado, a día de hoy, en su carrera (se ha ocupado de la dirección de fotografía en más de diez de sus filmes). Además, se trata de un relato importante en su filmografía (supuso su segunda nominación de la Academia a Mejor Fotografía, 1997). En cuanto a El hombre que nunca estuvo allí, pensamos que el uso de la técnica en blanco y negro puede aportar al estudio una mirada diferente sobre creación compositiva-cinematográfica. En referencia a Sicario, cabe decir que es el trabajo previo más importante antes de recibir el Premio de la Academia (2017). Por último, la selección de Blade Runner 2049 se debe a que su labor en este film ha recibido el reconocimiento de los académicos de la industria del cine, consiguiendo su primer Oscar en la categoría de Mejor Fotografía (2018).

\subsection{Categorías analizadas}

En relación a las variables analizadas -encuadre, color e iluminación- es preciso exponer su descripción:

El encuadre, muestra la tipología imperante, consecuentemente su intencionalidad expresiva. Se constituye con un total acumulado de 1.339. La cifra, al igual que su duración, difiere en cada una de las obras objeto de estudio ( $c f$. datos exactos en el epígrafe de resultados). Es necesario aclarar que las obras seleccionadas no tienen la misma duración, por ello, el estudio sobre esta primera variable está centrado en las escenas del planteamiento de la película (determinado mediante el paradigma de Field ${ }^{6}$ ), porque con ello nos aseguramos que el tiempo analizado sea lo más equiparado en cada uno de los filmes. La clasificación del encuadre se basa en la establecida por Salt (2006) y Brown (2008). La elaboración de una tabla (1) nos permite recoger las tipologías planteadas por estos autores, una breve descripción y su finalidad.

5 Debemos aclarar que Fargo, fue dirigida por Joel Coen, aunque el guion fue creado también por Ethan Coen. Habitualmente los dos hermanos firman la autoría de todas las obras, codirigen, guionizan...

6 Según Field (1979: 15), un guión tiene 120 páginas de extensión, lo que equivale a aproximadamente dos horas de duración. Es decir, cada cara del libreto se traduce en un minuto en la pantalla. Si atendemos a esto, y basándonos en su paradigma, el primer acto se alargaría durante la primera media hora de la cinta, el segundo duraría hasta los 90 minutos de la cinta y el tercero hasta el final de la misma. 
Tabla 1

\begin{tabular}{|c|c|c|c|}
\hline \multicolumn{2}{|c|}{ Tipo de encuadre } & Extensión/Descripción & Uso/Valor/Funcionalidad \\
\hline \multirow{6}{*}{$\begin{array}{l}\text { Primer } \\
\text { Plano }\end{array}$} & $\begin{array}{l}\text { Primerísimo } \\
\text { Primer Plano o } \\
\text { sangrado }\end{array}$ & Imagen del rostro: desde la barbilla hasta la cabeza & $\begin{array}{l}\text { - Función expresiva } \\
\text { - Aumenta la carga dramática }\end{array}$ \\
\hline & Largo & Imagen del cuerpo: desde la cintura hasta la cabeza & - Función descriptiva \\
\hline & Medio o busto & Imagen: parte superior del cuerpo & $\begin{array}{l}\text { - Función expresiva } \\
\text { - Aumenta la carga dramática }\end{array}$ \\
\hline & Medio o de torso & Imagen: parte posterior del cuerpo & - Función expresiva \\
\hline & Detalle & Imagen: ojos y boca & $\begin{array}{l}\text { - Función expresiva } \\
\text { - Intencionalidad dramática }\end{array}$ \\
\hline & Escorzo & Imagen: dos personajes, uno de espaldas y otro de frente & $\begin{array}{l}\text { - Función expresiva } \\
\text { - Conversaciones y relaciones entre } \\
\text { personajes (punto de vista) } \\
\text { - Identificación espectador (empatía con } \\
\text { el personaje) }\end{array}$ \\
\hline \multicolumn{2}{|c|}{ Plano Americano } & $\begin{array}{l}\text { Imagen: desde la cabeza hasta las piernas }(3 / 4 \text { partes del } \\
\text { cuerpo) }\end{array}$ & - Función narrativa \\
\hline \multicolumn{2}{|l|}{ Plano General } & $\begin{array}{l}\text { Imagen: escenario (lugar donde se desarrolla la acción), } \\
\text { con o sin personaje/s (cuerpo entero mostrado de lejos) }\end{array}$ & - Función descriptiva (contextualización) \\
\hline \multicolumn{2}{|l|}{ Plano Medio } & Imagen: desde la cabeza hasta la cintura & $\begin{array}{l}\text { - Función expresiva, ocasionalmente } \\
\text { descriptiva }\end{array}$ \\
\hline \multicolumn{2}{|l|}{ Plano Detalle } & $\begin{array}{l}\text { Imagen: ojos y/o boca del personaje u otra parte del } \\
\text { cuerpo o un objeto que tenga relevancia en la acción }\end{array}$ & - Función expresiva \\
\hline \multicolumn{2}{|c|}{ Plano Conjunto } & Imagen: dos o más actores (muestra el cuerpo entero) & - Función descriptiva \\
\hline \multicolumn{2}{|c|}{ Plano de Recurso } & $\begin{array}{l}\text { Imagen: objeto o personaje que no sea el principal } \\
\text { (relacionado con la escena) }\end{array}$ & $\begin{array}{l}\text { - Uso técnico (evitan el salto de eje) } \\
\text { - Informan o introducen elementos de } \\
\text { interés }\end{array}$ \\
\hline \multicolumn{2}{|c|}{ Plano de Reacción } & $\begin{array}{l}\text { Imagen: estímulo-respuesta de personaje en la escena } \\
\text { ante un suceso o una acción de otro }\end{array}$ & - Función expresiva \\
\hline \multicolumn{2}{|c|}{ Toma de Conexión } & $\begin{array}{l}\text { Imagen: personaje mirando algo y objeto o sujeto que } \\
\text { observa }\end{array}$ & - Función narrativa \\
\hline \multirow{3}{*}{ Toma inserto } & Práctico & Imagen: recurso usado por un personaje & - Función descriptiva (informa) \\
\hline & Énfasis & Imagen: personaje y su impacto en la acción & $\begin{array}{l}\text { - Función expresiva Conectan con la } \\
\text { acción principal }\end{array}$ \\
\hline & Atmósfera & Imagen: parte aislada de una escena & $\begin{array}{l}\text { - Función narrativa } \\
\text { - Uso en tono de humor o contrapunto } \\
\text { irónico }\end{array}$ \\
\hline
\end{tabular}

Fuente: elaboración propia basada clasificación de encuadres de Salt (2006) y Brown (2008)

Pese a analizar el uso de todos estos encuadres, nos detendremos en el empleo de los primeros planos o close-ups, dado que es un tipo de escala con gran poder a la hora de influir en las emociones del espectador, al acercarnos a las expresiones de los personajes. Aunque existen un gran número de encuadres, como veremos, son los primeros planos los que 
tienen la mayor carga dramática y consiguen captar más la atención del espectador: "cuanto más fuerte sea el motivo de usar un primer plano, este encuadre ayudará más a crear un hilo argumental más efectivo" (Mascelli, 1965: 195).

La información sobre los tipos de encuadre utilizados en cada uno de los metrajes escogidos se recoge en fichas de análisis -tablas ${ }^{7}$-. Su confección nos capacita para conocer cuáles son los planos más utilizados y su medición en la frecuencia de uso (número de veces empleado). En el apartado de resultados se mostrarán en gráficos los porcentajes referentes a esta unidad de análisis.

Tabla 2

\begin{tabular}{|c|c|c|}
\hline \multicolumn{3}{|c|}{ PLANTILLA DE CODIFICACIÓN } \\
\hline \multicolumn{3}{|c|}{ Información básica } \\
\hline \multicolumn{2}{|c|}{ Nombre de la película } & \\
\hline \multicolumn{2}{|c|}{ Duración de la muestra } & \\
\hline \multicolumn{2}{|c|}{ Número total de encuadres } & \\
\hline \multicolumn{3}{|c|}{ Tipos de encuadre Cuantificación/Frecuencia $\left(\mathrm{N}^{\circ}\right)$} \\
\hline \multirow{6}{*}{ Primer Plano } & \multicolumn{2}{|c|}{ Primerísimo Primer Plano } \\
\hline & \multicolumn{2}{|l|}{ Largo } \\
\hline & \multicolumn{2}{|c|}{ Medio o busto } \\
\hline & \multicolumn{2}{|c|}{ Medio o de torso } \\
\hline & \multicolumn{2}{|l|}{ Detalle } \\
\hline & \multicolumn{2}{|l|}{ Escorzo } \\
\hline \multicolumn{3}{|l|}{ Plano Americano } \\
\hline \multicolumn{3}{|l|}{ Plano General } \\
\hline \multicolumn{3}{|l|}{ Plano Medio } \\
\hline \multicolumn{3}{|l|}{ Plano Detalle } \\
\hline \multicolumn{3}{|l|}{ Plano Conjunto } \\
\hline \multicolumn{3}{|l|}{ Plano de Recurso } \\
\hline \multicolumn{3}{|l|}{ Toma de Reacción } \\
\hline \multicolumn{3}{|l|}{ Toma de Conexión } \\
\hline \multirow{3}{*}{ Toma Inserto } & \multicolumn{2}{|l|}{ Práctico } \\
\hline & \multicolumn{2}{|l|}{ Énfasis } \\
\hline & \multicolumn{2}{|l|}{ Atmósfera } \\
\hline
\end{tabular}

Fuente: elaboración propia basada en los distintos planos acuñados por las teorías sobre encuadre y planificación de Salt (2006) y Brown (2008)

$7 \quad$ No hemos aportado específicamente todas las tablas por film estudiado en esta publicación, debido a su extensión, pero sí enunciaremos los datos más significativos acompañándolos con un gráfico en el que se establecen los porcentajes que resumen la presencia y/o repetición del uso de la planificación. 
El color es la segunda categoría sometida a estudio. Mediante el color pretendemos conocer qué intenta expresar, comunicar, Roger Deakins, observando la recurrencia de tonos concretos. Entendiendo que la percepción de los colores se puede considerar algo subjetivo, recurrimos a los estudios de Heller (2008) sobre las sensaciones que producen, aplicando sus teorías a los aspectos que se muestran en los relatos cinematográficos. También es necesario considerar que este elemento, además de relacionarse con determinadas emociones, puede aportar connotaciones propias en cada film: se emplean para identificar situaciones, en momentos específicos de la trama e incluso predomina y/o acompaña a los personajes. En este sentido, el color adquiere gran importancia en el lenguaje visual y, por ello, se ha decidido analizar la película en su conjunto, no fragmentar el análisis del film, dado que reducir la muestra podría afectar al significado de la obra (pérdida de datos, dispersión en la lectura) y, consecuentemente, en la comprensión de la manera en la que se comunica.

En el cine, el color se ha convertido en la herramienta que nos acerca a la realidad y hace más creíbles las historias. De igual modo, transmite y/o genera emociones o sensaciones, por tanto, la obra adquiere un sentido dramático. Vinculamos, como venimos diciendo, las teorías del color de Heller con la gramática de cada una de las cintas seleccionadas en el apartado de resultados del presente texto. Las tonalidades ${ }^{8}$, cuyo uso es predominante en las películas objeto de estudio e interviene en la semántica ${ }^{9}$ de las mismas, se muestran en la siguiente tabla:

Tabla 3

\begin{tabular}{|c|c|}
\hline Color & Función expresiva/Conceptos \\
\hline Blanco & $\begin{array}{l}\text { - Equivale a vacío, asociado con la ausencia de sentimientos } \\
\text { - La "muerte blanca" es la muerte por congelación } \\
\text { - Color de los muertos, los espíritus y los fantasmas Los rostros de los muertos pierden los colores de la vida } \\
\text { - Relación: el comienzo del mundo fue el comienzo del mal } \\
\text { - Usado en rituales religiosos (sacrificios para expiar vidas humanas) } \\
\text { - El significado político: rendición } \\
\text { - Vinculado con la verdad }\end{array}$ \\
\hline Rojo & $\begin{array}{l}\text { - El color del peligro, de lo demoniaco, de la sangre (representa violencia, agresividad, guerra, destrucción, } \\
\text { crueldad, ira, rabia, exceso, estrés, peligro, maldad, riesgo, irritación) } \\
\text { - Rojo y negro: peligro y prohibición } \\
\text { - Color de lo inmoral } \\
\text { - Asociado al concepto de fuerza, poder, fuego (rojo litúrgico) } \\
\text { - Uso religioso, rituales primitivos: sacrificios con derramamiento de sangre }\end{array}$ \\
\hline Negro & $\begin{array}{l}\text { - Muerte, luto, oscuridad, suciedad, negatividad, falta de luz, soledad, dolor, tristeza, pena, depresión, } \\
\text { misterio } \\
\text { - Fuerza, poder }\end{array}$ \\
\hline
\end{tabular}

8 Los colores se exponen en la tabla por orden de aparición en cada una de las obras ( $c f$. en epígrafe de resultados) y sus connotaciones variarán en las distintas situaciones y en función de otras tonalidades que acompañen.

9 Únicamente se han incluido modos enunciativos, expresivos, de los colores dominantes que guardan relación con el discurso de los filmes objeto de estudio. 


\begin{tabular}{|c|c|c|}
\hline \multirow{2}{*}{ Beige } & $\begin{array}{l}\text { Beige- } \\
\text { marrón }\end{array}$ & $\begin{array}{l}\text { - Color de lo acogedor, lo cotidiano, lo corriente. } \\
\text { - Valorado positivamente en los espacios habitables. } \\
\text { - Crea el clima ideal en una habitación. }\end{array}$ \\
\hline & $\begin{array}{l}\text { Beige- } \\
\text { amarillo } \\
\text { pálido }\end{array}$ & $\begin{array}{l}\text { - Color de los traidores (Antigua tradición: Judas-Iscariote traicionó a Jesús; quien aparece frecuentemente } \\
\text { representado con una túnica de color amarillo pálido). }\end{array}$ \\
\hline \multicolumn{2}{|l|}{ Azul } & $\begin{array}{l}\text { - Valores vinculados: seguridad, inteligencia, reflexión, actividad mental, racionalidad, discreción, precisión, } \\
\text { orden, rectitud, honestidad, profesionalidad, solidez, sobriedad, seriedad, legitimidad, legalidad, justicia, } \\
\text { moralidad. } \\
\text { - Relacionado también con la pureza, ligereza, la libertad, espiritualidad, grandeza, vida, energía, vitalidad, } \\
\text { fuerza, alegría, esperanza, bondad, positividad y felicidad. }\end{array}$ \\
\hline \multicolumn{2}{|l|}{ Amarillo } & $\begin{array}{l}\text { - Representa a lo bello y valioso. } \\
\text { - Símbolo de riqueza (dorado). } \\
\text { - Términos relacionados: lujo, poder, abundancia, prosperidad, opulencia... } \\
\text { - Vinculado a los dioses solares (Helios, Apolo, Sol), divinidad-Leyendas: donde hay flores amarillas, hay oro } \\
\text { enterrado. } \\
\text { - Color de la iluminación mental, de la sabiduría. }\end{array}$ \\
\hline \multicolumn{2}{|l|}{ Verde } & $\begin{array}{l}\text { - Símbolo de la vida en el sentido más amplio. } \\
\text { - Color de la esperanza. } \\
\text { - Otros conceptos relacionados: energía, libertad, salud y equilibrio. } \\
\text { - Asociado con la naturaleza y el campo. La naturaleza verde es grandiosa. El verde está relacionado al bien- } \\
\text { estar material y espiritual. }\end{array}$ \\
\hline
\end{tabular}

Fuente: elaboración propia basada en las teorías de Heller (2008)

A través de la tercera de las variables analizadas, la luz, intentamos hallar los momentos en los que Deakins, en las cuatro películas, ha tratado de transmitir al espectador algún tipo de emoción o de información mediante el empleo de un tipo u otro de iluminación, consecuencia de las manifestaciones simbólicas de sus códigos. Como sabemos, el empleo y control de la luz es una de las destrezas más importantes del trabajo de dirección de fotografía y recurso fundamental en la narrativa audiovisual. Para su estudio atendemos a los planteamientos de Gutiérrez San Miguel (2006) que nos han permitido apreciar las tres técnicas de iluminación utilizadas:

- zonas: constituida por una sucesión luminosa de mayor a menor o al contrario. Los puntos de luz moldean el espacio resaltando lugares fuertes de la acción narrativa. En un mismo plano hay dos focos importantes de atención para el espectador. A través de ellos se resaltan las dos escenas de la narración que se van a dar en un mismo tiempo;

- manchas: el uso de focos potentes en ciertas partes resaltan personajes u objetos que van a tener una intencionalidad dramática, el resto queda en semioscuridad. Tipo de luz dramática utilizada para resaltar la tensión (Gutiérrez San Miguel, 2020: 301);

- masas: caracterizada por otorgar a la imagen una gradación lumínica semejante a la producida por la luz natural.

Al igual que con el color, la luz también se observa desde el principio hasta el final de cada uno de los filmes para poder ofrecer las diversas aportaciones expresivas. 
En síntesis, intentando alcanzar la finalidad prevista en el texto, involucramos diversas metodologías. La hibridación contribuye a realizar una triangulación de datos (Gómez-Diago, 2010).

\section{Resultados}

Procedemos a exponer los resultados obtenidos a partir de la muestra analizada: las cuatro películas elegidas en las que Deakins ha trabajado como director de fotografía. Con el fin de mantener una estructura organizada, trasladamos los datos relativos de cada una de estas obras, siguiendo su disposición cronológica respecto a los años en los que han sido producidas, comenzando por la más antigua (Fargo) y finalizando con la más reciente (Blade Runner 2049). Respecto a la primera variable estudiada, se ha recogido el número de encuadres y los tipos de escala del plano empleados mediante la elaboración del modelo de tabla (incluida en apartado anterior). Esta medición permite extraer porcentajes e interpretar datos.

En cuanto a las otras dos variables: color e iluminación, también mostramos los resultados de una manera descriptiva. Excepcionalmente, la unidad de análisis del color no ha sido estudiada en la obra El hombre que nunca estuvo allí, porque aunque fue rodada con esta técnica, su tratamiento final es en blanco y negro. Sin embargo las connotaciones sobre esta cita quedan enunciadas gracias a los valores extraídos a partir de los resultados más significativos del tipo de sistema de luz aplicado con una determinada intención comunicativa, emocional.

\subsection{Fargo}

Un hombre apocado y tímido, casado con la hija de un millonario que le impide disfrutar de su fortuna, decide contratar a dos delincuentes para que secuestren a su mujer con el fin de montar un negocio propio con el dinero del rescate. Pero, por una serie de azarosas circunstancias, al secuestro se suman tres brutales asesinatos, lo que obliga a la policía a intervenir ${ }^{10}$.

\subsubsection{Frecuencia de encuadres y primeros planos}

De acuerdo con la codificación realizada acerca de la variable -tipos de encuadre- en la película Fargo, durante los primeros 32:50 de metraje, se ha observado que los primeros planos han sido los más utilizados. En concreto 170 veces, respecto al número total, 296. El plano medio ha sido el segundo encuadre más usado en 30 ocasiones. Los menos empleados han sido el plano americano, el inserto y el plano recurso, que aparecen 5 veces cada uno.

10 Disponible en: https://www.filmaffinity.com/cl/film336111.html 
Gráfico 1. Porcentajes sobre los tipos de encuadres

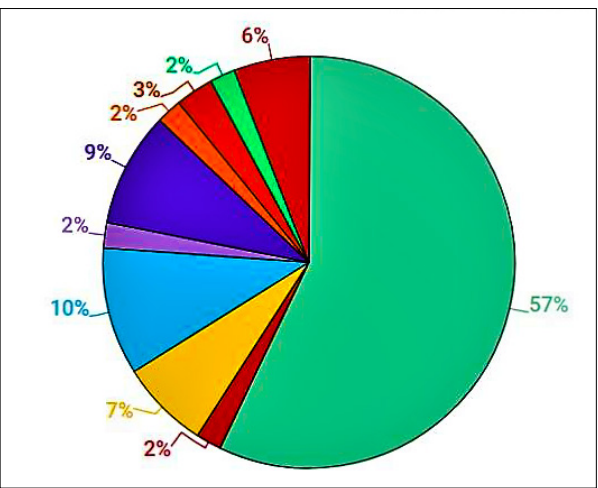

Primer Plano

Plano Americano Plano General

Plano Medio Plano Detalle Plano Conjunto

Plano de Recurso

Toma de Reacción Inserto

Toma de conexión

Fuente: Elaboración propia

Atendiendo concretamente al uso de primeros planos y teniendo en cuenta su división, el más utilizado es el medio o busto, que aparece en 78 ocasiones. Los siguientes más usados son el largo y el escorzo, 38 y 29 veces respectivamente. Los más inusuales son el de torso (5 muestras) y se ha detectado una carencia del plano detalle.

Gráfico 2. Porcentajes sobre el uso de los distintos tipos de primeros planos

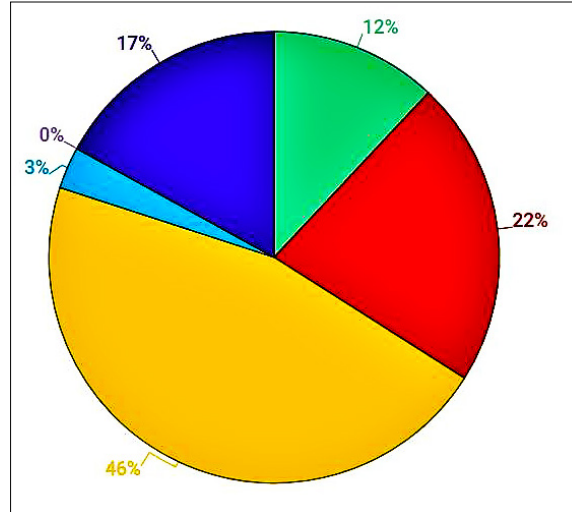

Primerísimo Primer Plano

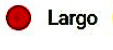

Medio o busto

Plano Medio o de torso

Detalle

Escorzo

Fuente: Elaboración propia

\subsubsection{El color}

El color en Fargo se ha empleado de una manera intencionada y dramática. Dicha tensión, se consigue al poner en relación este recurso con personajes o situaciones concretas. Bien es cierto que en esta obra el uso del blanco [ausencia del color (Heller, 2008: 164)] se hace omnipresente. La recurrencia del blanco se observa en los paisajes nevados de las localizaciones 
que representan los estados de Dakota del Norte y Minesota (uso del color para dar credibilidad a la historia y mostrar la realidad). También parece acentuar la falta de moral y empatía de algunos de los personajes: uno de los dos delincuentes, Gaear Grimsrud (Peter Stormare), con el que contacta Jerry Lundegaard (William H. Macy) para secuestrar a su esposa, aparece vestido durante toda la película con un jersey de color blanco (figura 1). No es baladí que Grimsrud adopte el papel de un hombre carente de ética y compasión (carácter insensible: $c f$. en tabla 3). Paralelamente, el blanco genera contrastes con otros colores, como pueden ser el negro y el rojo o granate que también tienen una presencia destacable en la obra. El rojo está estrictamente relacionado con la muerte a lo largo de todo el film a través de distintas ropas. Todos los personajes que en algún momento llevan puesto alguna prenda de este color o de la misma gama, generalmente granate, acaban siendo asesinados durante el film. Podemos observar esta conexión por primera vez durante la escena donde Jean Lundegaard (Kristin Rudrüd) es secuestrada. En esta ocasión ella está tejiendo un jersey de este color (figura 2).

Figura 1. Gaear con jersey blanco

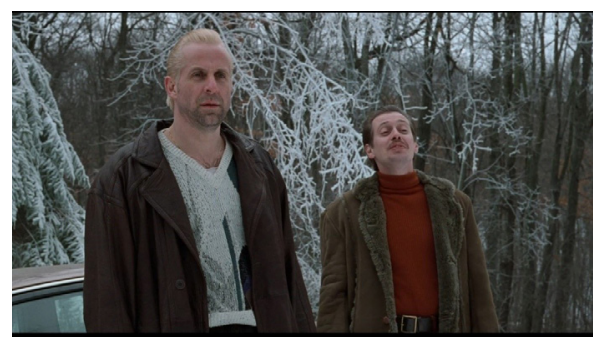

Fuente: Fotograma Fargo
Figura 2. Jean teje con lana granate

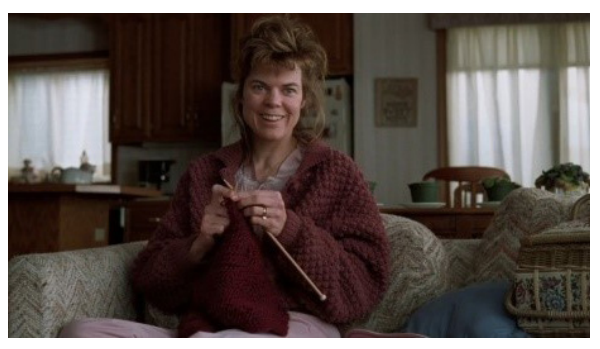

Fuente: Fotograma Fargo

También viste de granate (figura 3) el policía que morirá más avanzado el film. Poco después, dos personas observan el suceso y se desencadena una persecución en la que serán aniquilados, uno de estos testigos lleva puesto un abrigo rojo. Otro de los personajes ataviado con un jersey de esta misma tonalidad es Wade Gustafson (Harve Presnell), padre de Jean. El uso de este color adquiere relevancia si tenemos en cuenta que este personaje, viste esta prenda en el momento que Carl (Steve Buscemi) acaba con su vida (figura 4). A su vez, a Carl, que también perece de la misma forma que los demás personajes, podemos verlo con una prenda de las mismas características (retomar figura 1).

Figura 3. Policía con chaqueta granate

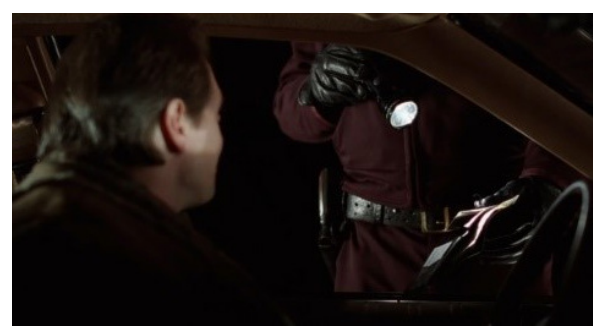

Fuente: Fotograma Fargo
Figura 4.W. G. y jersey rojo oscuro

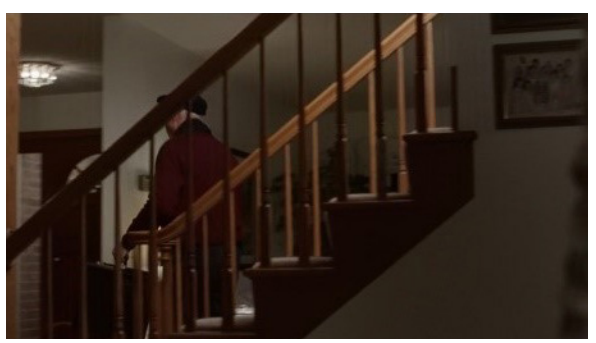

Fuente: Fotograma Fargo 
Tras el asesinato del policía se inicia una persecución entre dos coches, uno de los cuales colisiona. En esta escena se produce de nuevo el juego de tonos con el blanco: el color rojo y el negro se reflejan sobre la nieve blanca (figura 5) y así el paisaje albo se tiñe de estas otras dos tonalidades. Tomando como referencia los estudios de Heller (2008), podemos comprobar que la autora relaciona directamente al rojo con la rabia y al negro con la muerte. Además, añade que la mezcla de estos dos colores, de la cual se obtiene el granate, está estrictamente ligada al concepto de peligro. Deducimos, por tanto, que también podría estarlo con la muerte.

Figura 5. Imagen teñida de rojo

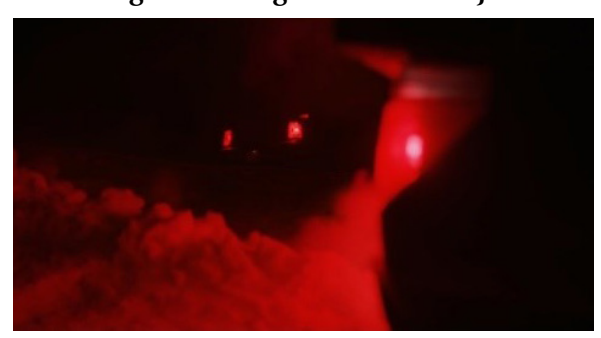

Fuente: Fotograma Fargo

\subsubsection{La iluminación}

En Fargo esta variable tiene un carácter funcional que consiste en aportar realismo en las localizaciones exteriores, paisajes oriundos en los que la luz es primordialmente natural. De esta manera, no se puede observar ninguna intencionalidad que vaya más allá que la de aportar veracidad a la historia, salvo en una excepción: escena donde el policía es asesinado y tiene lugar la persecución, mencionada en el apartado anterior. En esta escena, la iluminación se hace protagonista y observamos un uso intencionado de la luz por manchas, que se refleja directamente en los ojos de los dos secuestradores. Primer uso: la reflexión de la luz de los faros del coche patrulla, tras la muerte del agente, incide en el rostro de Carl salpicado con sangre. La finalidad de iluminación por manchas en este caso es centrar la mirada en la expresión de horror ante el suceso, aumentando la carga dramática de la escena (figura 6). Segunda utilización: durante la persecución se aprovecha este mismo tipo de iluminación para mostrar a Gaear. Ahora, la luz se centra de nuevo en la mirada de este personaje, fija en la carretera y en el coche al que sigue para que podamos ver el comportamiento y/o la acción del personaje, la ira y la ausencia de sentimientos (figura 7). 
Figura 6. Imagen expresión del horror

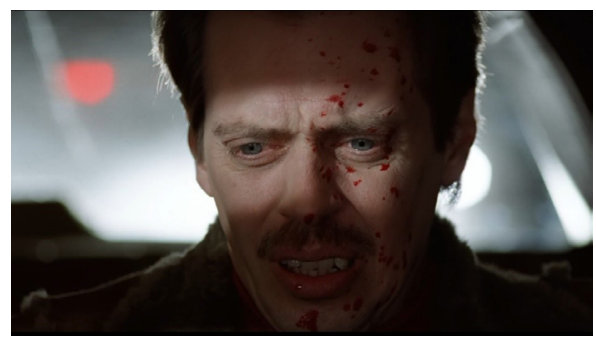

Fuente: Fotograma Fargo
Figura 7. Luz que indica la mirada

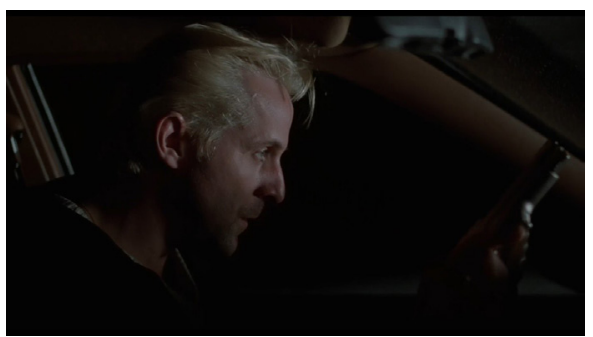

Fuente: Fotograma Fargo

Segundos más tarde, cuando Gaear se dispone a apretar el gatillo para matar a uno de los testigos, la luz trasera del coche se refleja en él y en la pistola con un color rojo que refuerza esa idea de rabia (figura 8).

Figura 8. Luz del automóvil, muestra al personaje

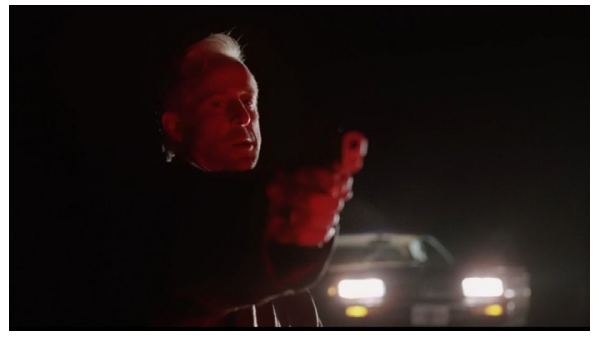

Fuente: Fotograma Fargo

\subsection{El hombre que nunca estuvo allí}

Verano de 1949. Ed Crane (Billy Bob Thornton), un introvertido barbero de un pueblecito del norte de California, se siente insatisfecho de su rutinaria vida. Las infidelidades de su mujer (Frances McDormand) le brindan la oportunidad de ejercer un chantaje que podría ayudarle a cambiar su apática existencia ${ }^{11}$.

\subsubsection{Frecuencia de encuadres y primeros planos}

El análisis del El hombre que nunca estuvo allí, durante el primer acto (42 minutos y 53 segundos), nos revela que los primeros planos son los más utilizados, al igual que ocurre con Fargo. En concreto 247 veces, respecto al cómputo global de 356 encuadres.

11 Disponible en: https://www.filmaffinity.com/cl/film570402.html 
Gráfico 3. Porcentajes sobre los tipos de encuadres

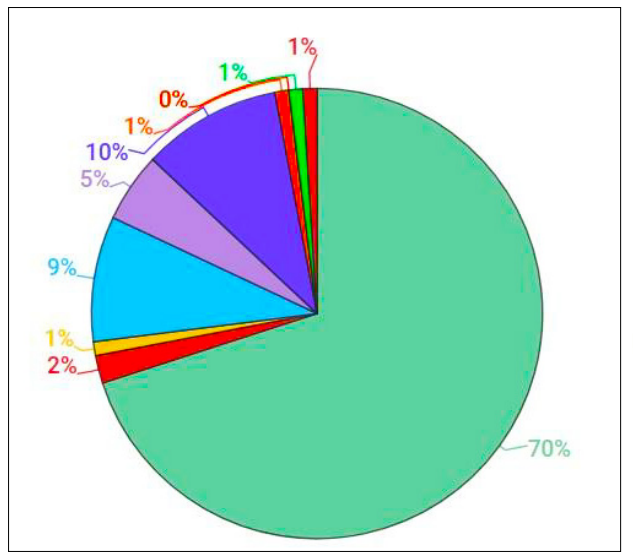

Primer Plano

Plano Americano

Plano General

Plano Medio

Plano Detalle

Plano Conjunto

Plano de Recurso

Toma de Reacción

Inserto

Fuente: Elaboración propia

El plano de conjunto aparece en 34 ocasiones, una más que el plano medio. El menos empleado es el plano recurso, tan solo en 2 apariciones. Se recurre al plano general y la toma de conexión en 3 imágenes. La toma de reacción es inexistente en esta obra.

Respecto a la presencia de primeros planos, el más utilizado es el medio o busto, se emplea en 79 ocasiones y el largo aparece 72 veces. Encontramos también una repetición en el uso del plano medio o de torso o el primerísimo primer plano, que se emplean 43 y 31 veces, respectivamente, y el escorzo en 21 composiciones. El menos utilizado es el plano el detalle, que se muestra en un único momento.

Gráfico 4. Porcentajes sobre el uso de los distintos tipos de primeros planos

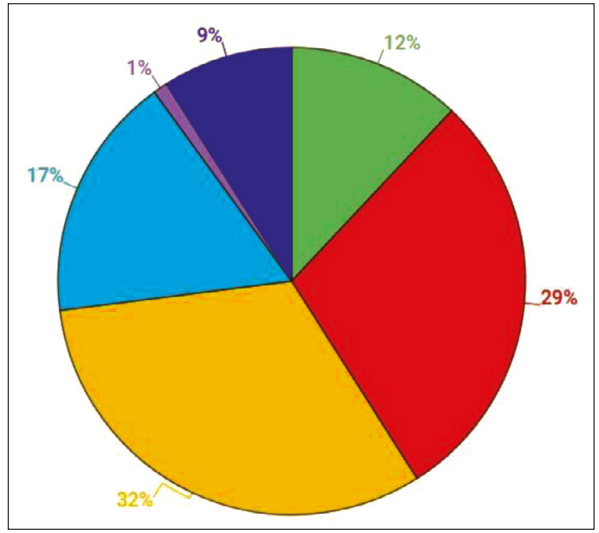

Primerísimo Primer Plano

Plano Medio o de torso

Fuente: Elaboración propia 


\subsubsection{Iluminación}

La iluminación en El hombre que nunca estuvo allí tiene una doble funcionalidad: expresiva y dramática. Esta película al modificarse a blanco y negro, hace que su iluminación difiera del resto de cintas seleccionadas para este estudio, principalmente por la manera de hacer este cine. Los trabajos carentes de color se caracterizan por estar rodados en su mayoría en decorados que se iluminan por partes con el objetivo de realzar objetos o personajes e intentar controlar mejor la luz sobre la escena (Tolan, 1941).

Las imágenes que conforman el film se caracterizan por tener poco grano. Dicha técnica dota de mayor calidad a la obra y permite obtener una textura única. Mediante el uso de un diafragma abierto se consigue una menor profundidad de campo y, consecuentemente, los fondos aparecen desenfocados. Eso se manifiesta de una forma mucho más evidente cuando la luz recae sobre los personajes para ensalzarlos (figura 9). Este aspecto se hace más notorio en aquellas escenas en las que la iluminación hace un efecto de contraluz (recurrente a lo largo del film), sitúa a los sujetos delante de la fuente luminosa y la cámara en posición lateral o detrás de ellos, empleando un sistema de luz directa, dura, intensa, logrando un efecto que añade dramatismo en la acción. Por ejemplo, el uso del contraluz con este objetivo lo podemos ver cuando el protagonista, Ed Crane (Billy Bob Thornton), está debatiendo si negociará con un extraño al que acaba de conocer, para ello tendrá que aportar una inversión 10.000 que intentará conseguir chantajeando al amante de su esposa (figura 10).

Figura 9. Luz directa

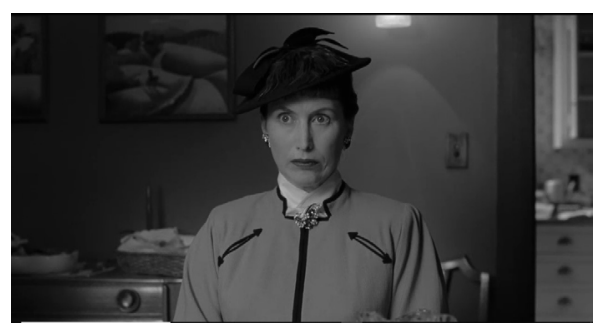

Fuente: Fot. El hombre que nunca estuvo allí
Figura 10. Contraluz

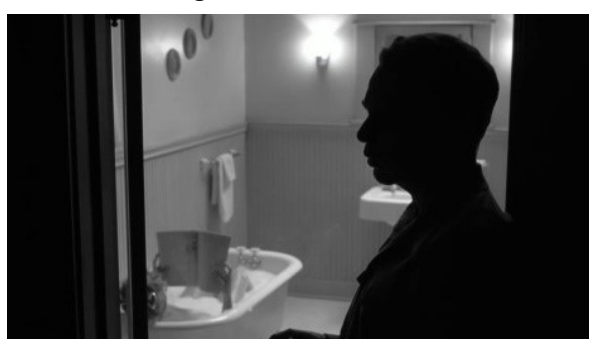

Fuente: Fot. El hombre que nunca estuvo allí

Este tipo de iluminación de contra volverá a repetirse más adelante, cuando Big Dave (James Gandolfini), el amante de la mujer de Ed le cuenta al mismo Ed que ha recibido una carta de soborno (figura 11). Y se usará de nuevo en el momento en el que el protagonista acude al despacho del amante (figura 12). Esta escena se caracteriza, además, por su escasa luminosidad. La intencionalidad de dejar esta imagen tan oscura incrementa el drama (técnica en coherencia con la narración: la tensión dramática es extrema, finaliza con un asesinato). 
Figura 11. Contraluz personajes rivales

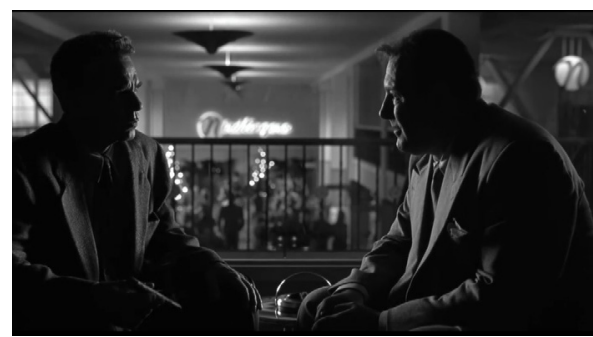

Fuente: Fot. El hombre que nunca estuvo allí
Figura 12. Penumbra en despacho

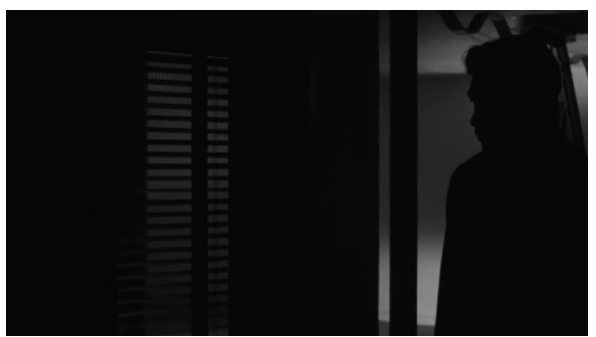

Fuente: Fot. El hombre que nunca estuvo allí

En otro instante de la cinta, Roger Deakins se sirve de un tipo iluminación por zonas: escena en la que Ed y Big Dave mantienen una pelea que termina con la muerte de este último, realizada en unos grandes almacenes con una luz muy deficiente y centrada en unos maniquís y en la escalera que da al despacho donde está teniendo el altercado. El conflicto violento entre los dos hombres se muestra ubicado en la parte superior y central de la imagen, al fondo y enfocado, usando de nuevo un contraluz mediante el que podemos ver a las dos siluetas golpeándose (figura 13).

Deakins también utiliza la técnica iluminación por manchas. Podemos verlo en la escena en la que Freddy Riedenschneider (Tony Shalhoud), el abogado de la esposa de Ed, realiza un monólogo donde plantea cómo va a afrontar una defensa ante el jurado, destacando su figura a contraluz, a partir de la que se proyecta una sombra pronunciada (figura 14).

Figura 13. Conflicto en almacenes

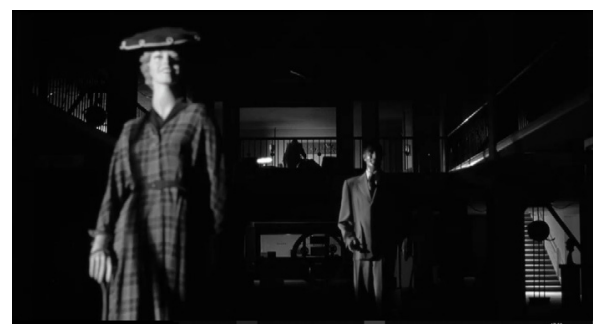

Fuente: Fot. El hombre que nunca estuvo allí
Figura 14. Ensayo defensa -juicio-

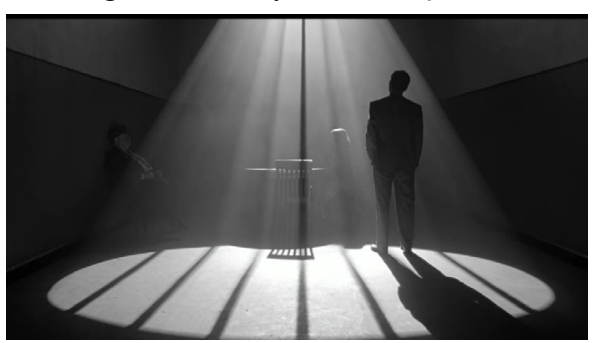

Fuente: Fot. El hombre que nunca estuvo allí

No obstante, el tipo de iluminación más dominante en este film, es la luz por masas. A modo de ejemplo cabe citar todas las escenas que se desarrollan en la peluquería y en exteriores, especialmente diurnos (figura 15). 
Figura 15. Imagen de la peluquería

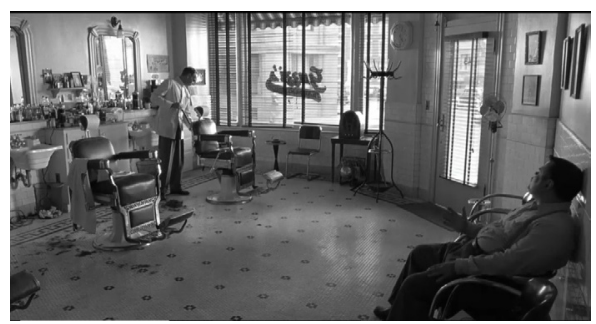

Fuente: Fot. El hombre que nunca estuvo allí

\subsection{Sicario}

En la zona fronteriza que se extiende entre Estados Unidos y México, la joven Kate Macer, una idealista agente del FBI, es reclutada por una fuerza de élite del Gobierno para luchar contra el narcotráfico. Bajo el mando de Matt Graver, un frío miembro de las fuerzas gubernamentales, y de Alejandro, un enigmático asesor, el equipo emprende una misión que lleva a la mujer a cuestionarse sus convicciones sobre la guerra contra los narcos y los límites de la ley ${ }^{12}$.

\subsubsection{Frecuencia de encuadres y primeros planos}

La observación de Sicario ha permitido cuantificar que se utilizan 188 primeros planos, respecto a los 422 encuadres conformados en un tiempo de 39 minutos con 25 segundos. El plano conjunto y el plano medio aparecen 61 y 52 veces, respectivamente. Se emplean 35 planos recursos, 26 tomas de conexión, 16 insertos y 12 planos detalle. El plano americano únicamente se usa una vez y la toma de reacción se muestra en 6 ocasiones.

Gráfico 5. Porcentajes sobre los tipos de encuadres
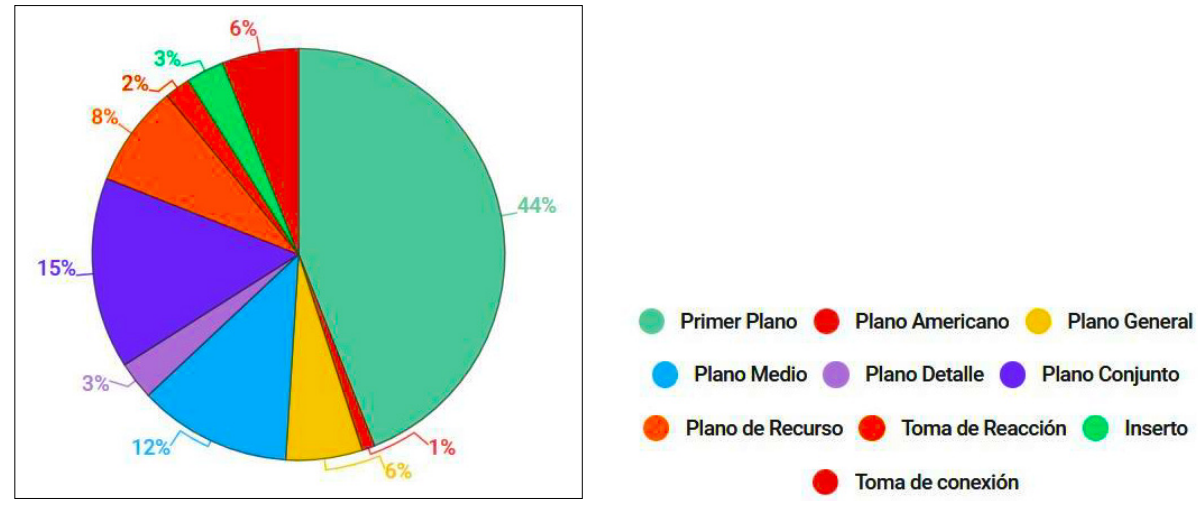

Toma de conexión

Fuente: Elaboración propia

12 Disponible en: https://www.filmaffinity.com/cl/film484192.html 
En cuanto al empleo de los primeros planos, podemos ver que el más utilizado es el de medio o busto, mostrado en 85 ocasiones de las 188 composiciones totales. El primerísimo primer plano aparece 42 veces, el largo 36 y el escorzo 17. Los menos recurrentes son el de torso, que aparece 8 veces, y se prescinde del detalle.

Gráfico 6. Porcentajes sobre el uso de los distintos tipos de primeros planos

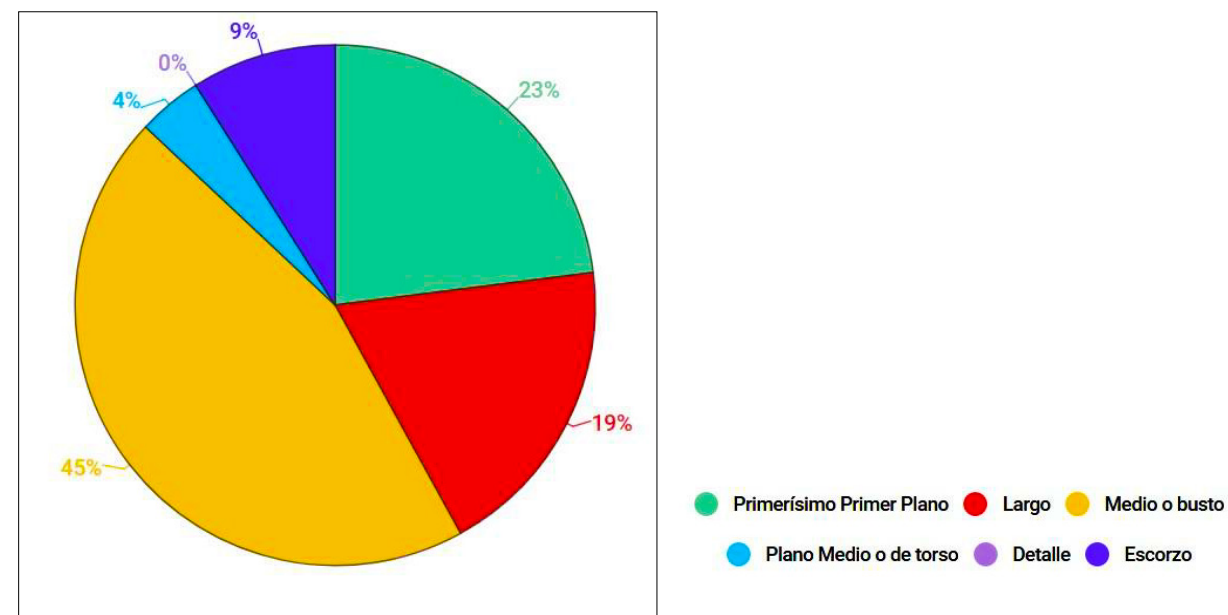

Fuente: Elaboración propia

\subsubsection{El color}

El color en Sicario se utiliza con propósito descriptivo. Destaca en este caso el uso de tonos beige (tono marrón) empleados en el vestuario, en escenarios (habitaciones) y en parte del decorado (muebles), para crear una atmósfera que envuelve a los personajes ( $c f$. en tabla 3), especialmente al de Alejandro (Benicio del Toro) y al de Matt (Josh Brolin). Llama la atención también la figura de Kate (Emily Blunt), ataviada con colores azules, en representación de la justicia y/o como manifestación de la legalidad ( $c f$. en tabla 3). La predominancia de este color en torno al personaje de Kate se evidencia en la escena en la que sube a un avión con Alejandro y Matt, donde el tono azul de su camiseta contrasta con el resto del lugar, repleto de tonos beige (figura 16). Además, en el transcurso de la historia se descubre que ha sido engañada y utilizada como una necesidad para poder realizar una maniobra en México y sus principios morales empiezan a verse comprometidos. A partir de este momento, observamos que su ropa (elemento icónico -camiseta azul-) que ha llevado puesta en la mayor parte de la película, cambia a gris y finalmente a blanco (asociado con la verdad: $c f$. en tabla 3), cuando se dispone a atentar contra Alejandro tras descubrir que él estaba trabajando para el cártel de Medellín (figura 17). 
Figura 16. Imagen ropa azul de Kate

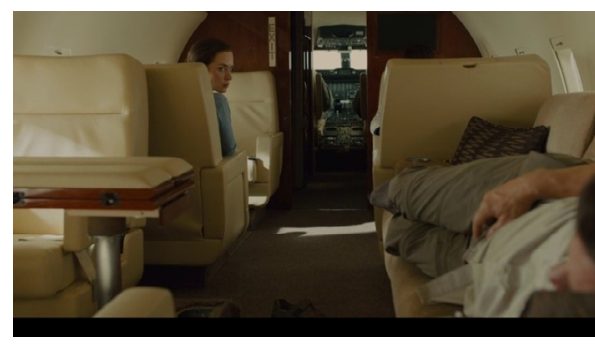

Fuente: Fotograma Sicario
Figura 17. Imagen de Kate (camiseta blanca)

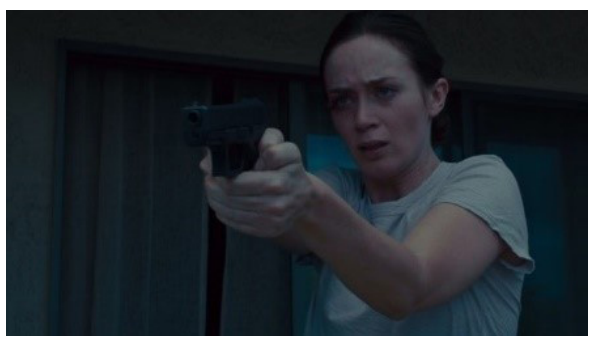

Fuente: Fotograma Sicario

De nuevo, el uso de beige (tono amarillo pálido) y azul se percibe en torno al personaje de Alejandro. Aparece rodeado en un primer momento con una tonalidad beige (puede tener una connotación relacionada con la traición: $c f$. en tabla 3), posteriormente se le asocia con la gama azulada, cuando creemos que está actuando en favor de la honestidad (escena en la que se quita la americana beige y se observa que viste con una camisa azul), en cuya acción se dispone a detener a uno de los líderes del cártel y el espectador aún no tiene conocimiento de los entresijos de la operación ni de que es un sicario (figura18). Conforme se vaya revelando la verdadera identidad de Alejandro comienza a vestir ropa más oscura, incluso generalmente se muestra en penumbra. Finalmente, su indumentaria es de color negro (figura 19).

Figura 18. Imagen ropa azul de Alejandro

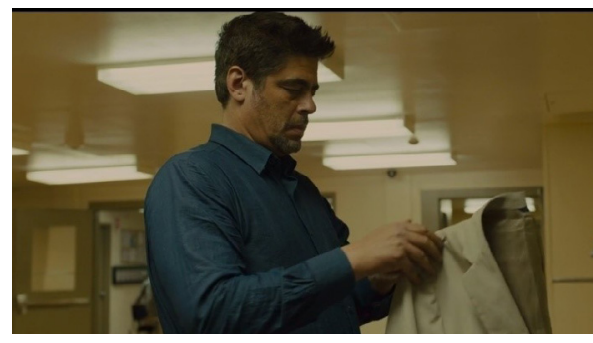

Fuente: Fotograma Sicario
Figura 19. Imagen Alejandro (ropa oscura)

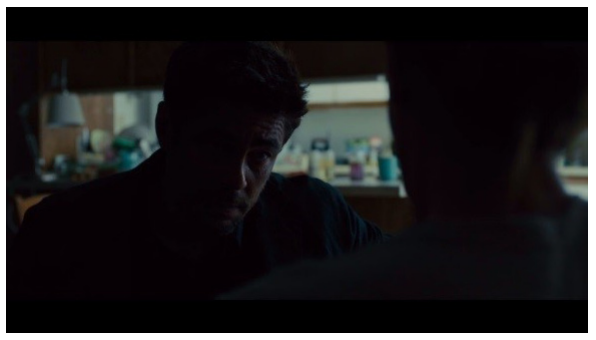

Fuente: Fotograma Sicario

\subsubsection{La iluminación}

La iluminación en Sicario se utiliza primordialmente como recurso descriptivo, aporta veracidad al relato. Aunque existe también un tratamiento de la luz con cierta intencionalidad, subrayamos el uso de iluminación por manchas para destacar personajes: en el comienzo del film la imagen de la protagonista, Kate, se construye mediante este sistema lumínico. La carga dramática se intensifica con el reflejo de color rojo en su rostro, a través de una cortina del mismo tono refractado en la pared (proyección del suceso que se pretende contar: se producirá una redada. Este resultado técnico de imagen con tintes rojizos también puede vincularse a los conceptos de violencia, sangre). Pensamos que la creación de este esquema lumínico es totalmente deliberada, dado que no se da en el plano anterior (figura 20). 
Figura 20. Imagen reflejo rojo en el rostro

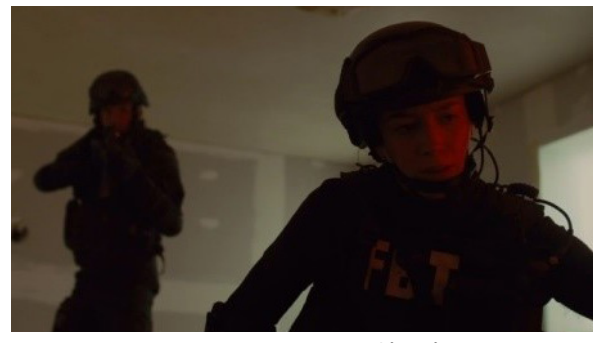

Fuente: Fotograma Sicario
Figura 21. Imagen-iluminación por manchas

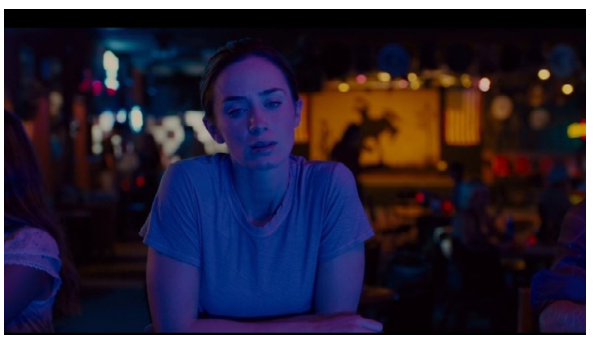

Fuente: Fotograma Sicario

Además, esta iluminación por manchas se aplica para aislar personajes, por ejemplo: escena en un bar, donde la luz enfoca al personaje de Kate para apartarla de todo lo que la rodea, cuya connotación revela que está absorta en sus pensamientos (figura 21), máxime cuando anteriormente se ha visto al FBI prohibirle emprender acciones legales contra el cártel para evitar el fracaso de la operación. Asimismo, puede destacarse el uso de contraluces que aumentan la tensión, la carga expresiva. Citamos un instante clave del film, realizado mediante luz de contra, que nos anuncia la incursión que va a tener lugar en uno de los túneles que usa el cártel para el tráfico de droga, de ahí la fuerza en su construcción (figura 22). Deakins recurre de nuevo a esta técnica con el objetivo de subrayar la figura de Alejandro, cerrando su arco argumental, dispuesto a acabar con la vida del líder del cártel que asesinó a su mujer e hija (figura 23).

Figura 22. Contraluz preludio del clímax

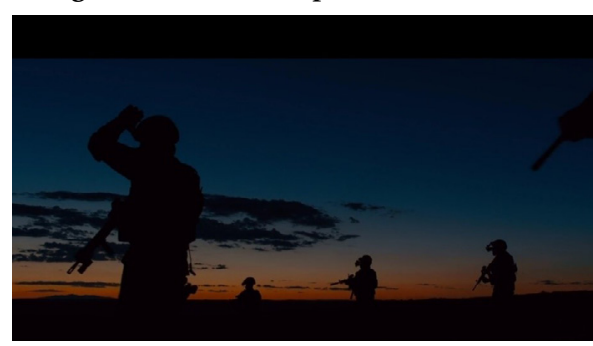

Fuente: Fotograma Sicario
Figura 23. Alejandro a contraluz

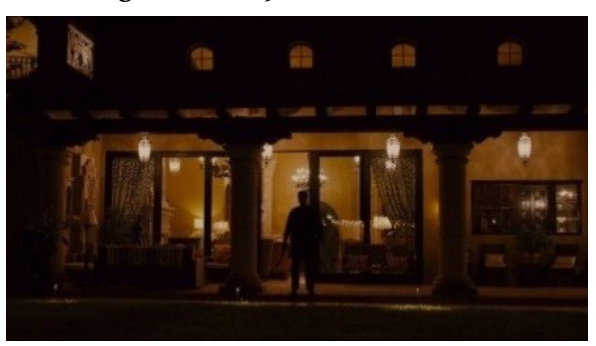

Fuente: Fotograma Sicario

Todos estos momentos de la obra han sido conformados mediante una iluminación que se aleja de un fin descriptivo, consigue que la puesta en escena sea totalmente esteticista, efectista, y muy cuidada plásticamente. 


\subsection{Blade Runner 2049}

Treinta años después de los eventos del primer film, un nuevo blade runner, K (Ryan Gosling), descubre un secreto profundamente oculto que podría acabar con el caos que impera en la sociedad. El descubrimiento de K le lleva a iniciar la búsqueda de Rick Deckard (Harrison Ford), un blade runner al que se le perdió la pista hace 30 años ${ }^{13}$.

\subsubsection{Frecuencia de encuadres y primeros planos}

Relativo a Blade Runner 2049, podemos observar que el encuadre más utilizado en el primer acto, cuya duración se extiende hasta el minuto 28:31, ha sido el primer plano, 124, de 275 encuadres en total. Conforman esta suma global, 52 de conjunto, 29 planos detalle, 20 planos medios, 17 generales, 15 insertos, 8 tomas de conexión, 7 planos recurso, 2 imágenes construidas con plano americano y una única toma de reacción.

Gráfico 7. Porcentajes sobre los tipos de encuadres

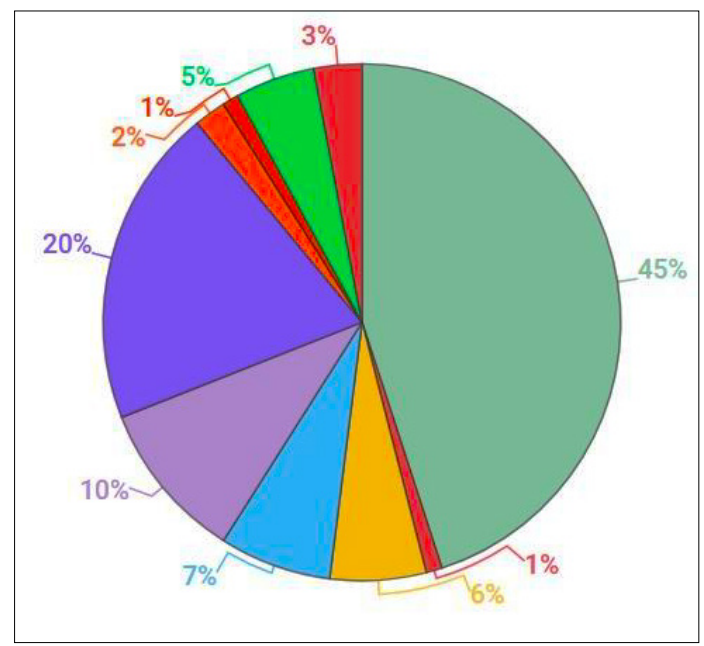

Primer Plano

Plano Americano

Plano General

Plano Medio

Plano Detalle

Plano Conjunto

Plano de Recurso

Toma de Reacción

Inserto

Fuente: Elaboración propia

Toma de conexión 
Gráfico 8. Porcentajes sobre el uso de los distintos tipos de primeros planos

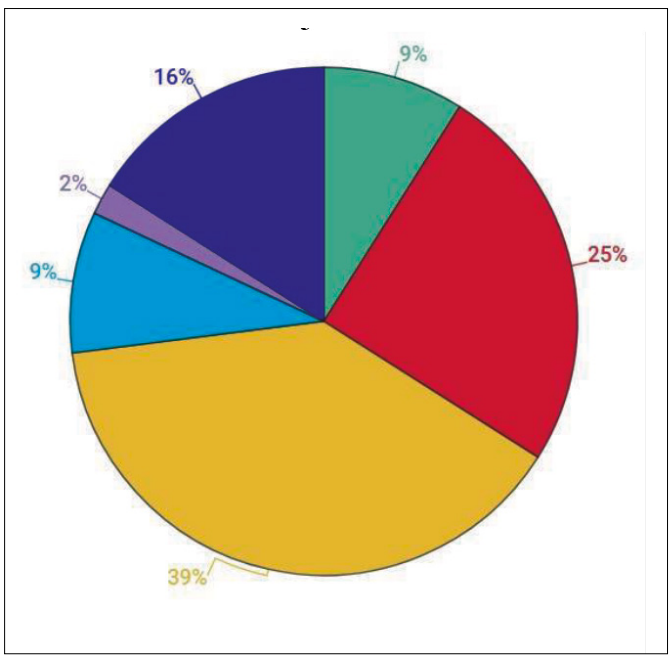

Fuente: Elaboración propia

Los primeros planos vienen representados por 49 medios o de busto y los largos y de escorzo han sido utilizados 31 y 20 veces respectivamente. Las escalas con menos número de apariciones, 11, son el primerísimo primer plano y el plano medio o de torso. El plano detalle solamente se muestra en dos situaciones.

\subsubsection{El color}

La finalidad del color en Blade Runner 2049 es esencialmente expresiva y adquiere gran relevancia en la construcción y discurrir de la película que tiene como tema central la creación de un mundo futurista. Comprobaremos, por tanto, cómo diferentes pigmentos se relacionan directamente con diversos aspectos de la trama, implícita o explícitamente.

El color el amarillo es una constante en el entorno del protagonista, un replicante encargado de llevar a cabo una investigación, el oficial K. Ya en la imagen de apertura puede apreciarse esta dominante: K acude a zona solitaria en la que puede observarse una casa que parece estar abandonada. Se trata de un escenario con una propuesta muy orgánica (tonos tierra, marrones, mezclados con grises), en la que destaca la puerta amarilla (figura 24). Posteriormente, en el mismo lugar, descubre la primera pista, concretamente, encuentra flores del mismo color (figura 25). 
Figura 24. Imagen de inicio: puerta amarilla

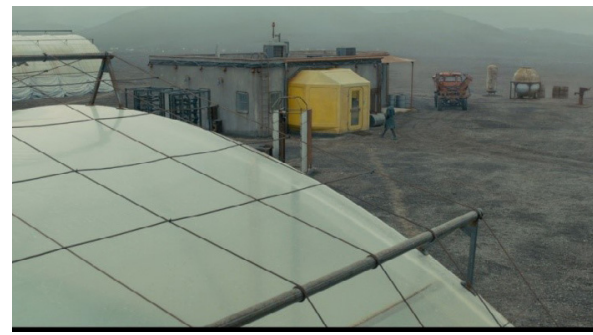

Fuente: Fotograma Blade Runner 2049
Figura 25. K halla flores amarillas (señal)

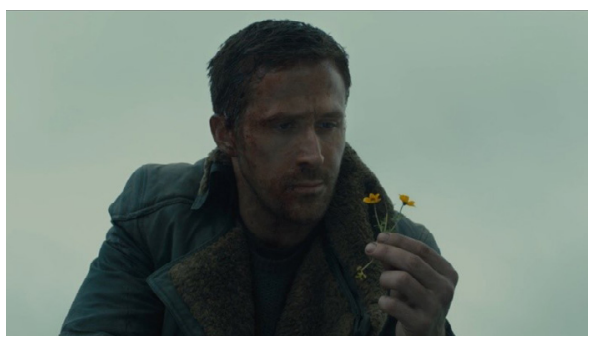

Fuente: Fotograma Blade Runner 2049

Más adelante, K recibe una llamada. Detrás de su figura se sitúa un cartel luminoso con letras de color amarillo-anaranjado, elemento que puede llegar a reforzar la idea seguir adelante con el caso (figura 26). Como hemos apuntado, la presencia de esta tonalidad relacionada con el personaje de K se mantiene durante todo el film. Otra referencia: su visita a la fábrica de replicantes, bañada en una atmósfera amarilla (figura 27). Pero, también dicha factoría se tiñe de color dorado, que concuerda con el propio texto del film: la compañía se posiciona como la más importante del mundo tras salvar al planeta de la catástrofe (figura 28).

Figura 26. K con cartel luminoso

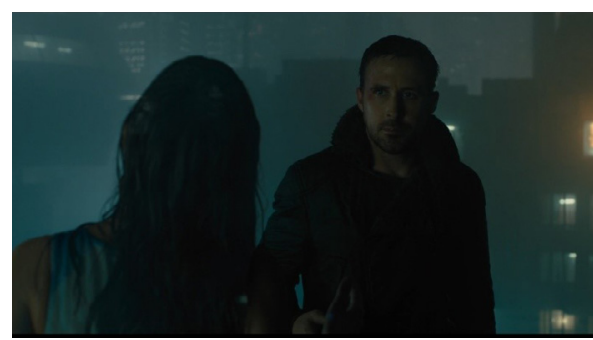

Fuente: Fotograma Blade Runner 2049
Figura 27. Fábrica de replicantes

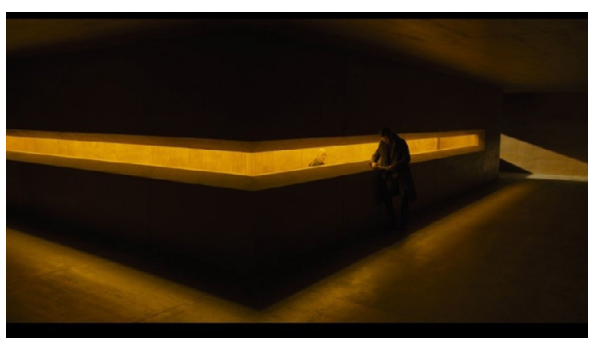

Fuente: Fotograma Blade Runner 2049

Igualmente, el sentido del color amarillo en la obra, se consolida al descubrir que una replicante ha tenido un hijo, mujer por la que Deckard se sintió atraído en Blade Runner (Ridley Scott, 1982). Esta tonalidad se empieza a asociar con estos personajes e incluso con otros replicantes presentados con un fondo teñido de un matiz ocre dorado (figura 29). 


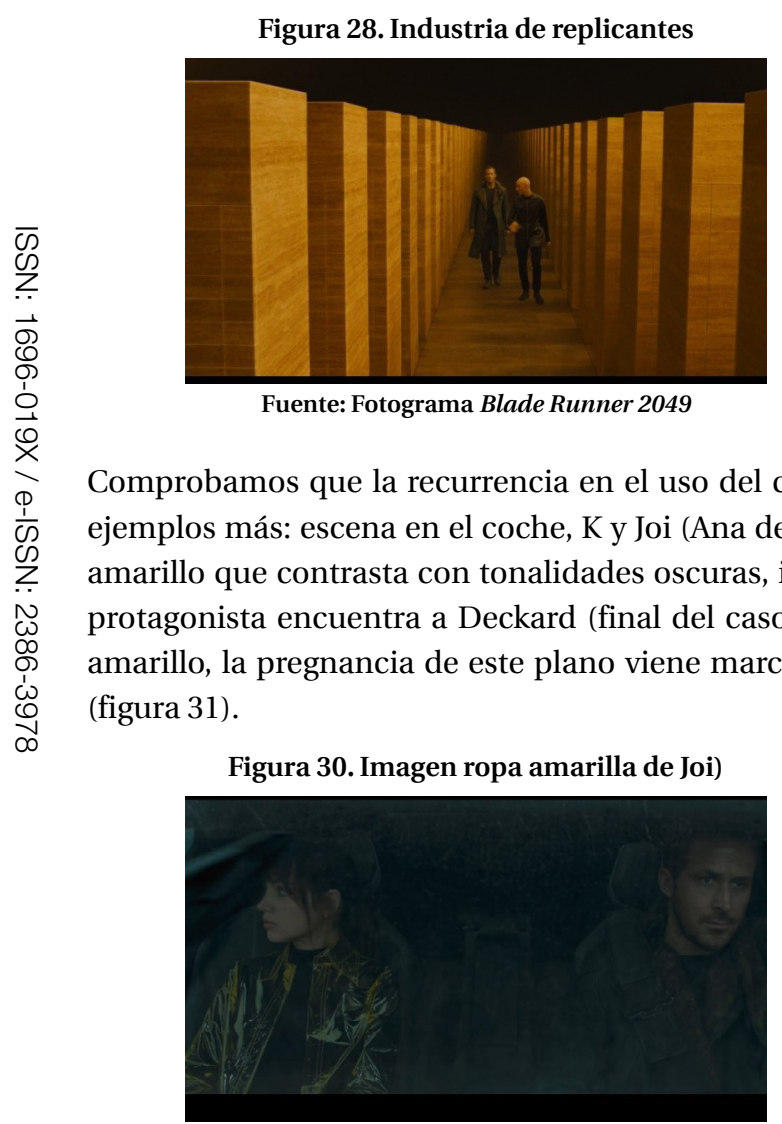

Fuente: Fotograma Blade Runner 2049 (figura 31).
Figura 29. Replicantes, fondo ocre dorado

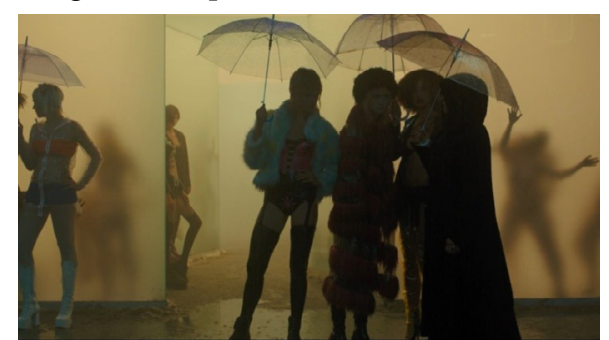

Fuente: Fotograma Blade Runner 2049

Comprobamos que la recurrencia en el uso del color amarillo puede apreciarse durante todo el relato. Señalamos dos ejemplos más: escena en el coche, K y Joi (Ana de Armas) siguen con la investigación. Ella lleva puesto un chubasquero amarillo que contrasta con tonalidades oscuras, incluso con matices en negro (figura 30); imagen de cierre en la que el protagonista encuentra a Deckard (final del caso), construida con una atmósfera de color naranja, intensificación del amarillo, la pregnancia de este plano viene marcada por el uso de este tono que parece alcanzar su máxima expresión

El verde, color que representa, entre otros conceptos, la vida ( $c f$. en tabla 3: los estudios de Heller así lo esbozan y es posible asociarlo con el significado de la película), adquiere importancia en Blade Runner 2049. Nos detenemos en el mensaje implícito de la obra que contiene la pregunta: ¿qué nos hace humanos? La respuesta no es el fenómeno del nacimiento en sí, pues el film habla acerca del puro hecho de vivir, acontecimiento que nos convierte en personas, así como del acto de tomar nuestras propias decisiones y ser libres. Deakins manifiesta la idea de libertad en el personaje de Joi, que se mueve de manera autónoma en un entorno bañado en este color (figura 32). De igual modo, cuando K sospecha que podría ser hijo de una replicante la imagen se crea con una dominante que contiene dicho pigmento (figura 33). 
Figura 32. Imagen de Joi (signo de libertad)

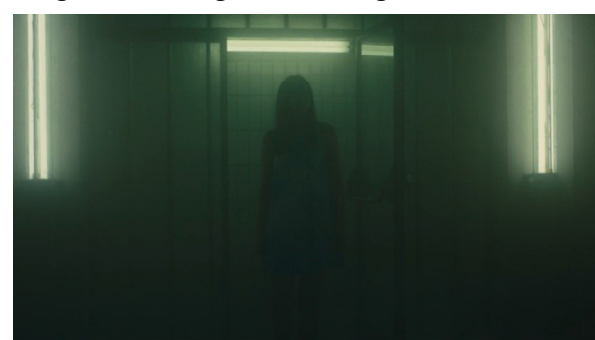

Fuente: Fotograma Blade Runner 2049
Figura 33. K reflexiona sobre su origen

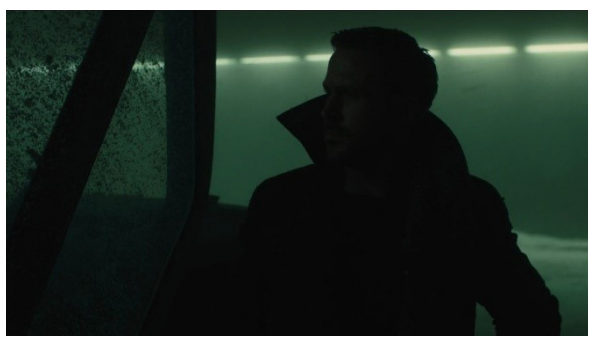

Fuente: Fotograma Blade Runner 2049

Cabe también referenciar la escena en el bosque, donde puede verse a la hija de Deckard y la replicante. Aunque se trata de un holograma, no vive realmente, dado que está esclavizada, un estado que produce cierta ruptura con la filosofía del film (figura 34).

Figura 34. Imagen-holografía del bosque

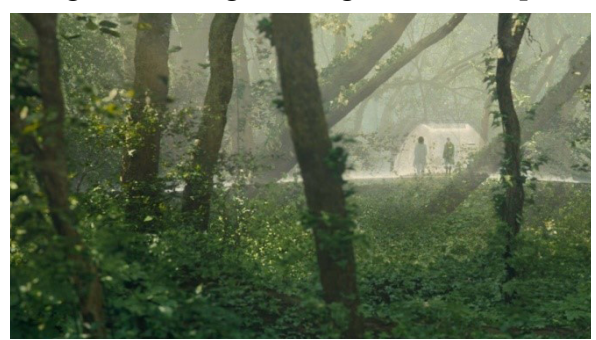

Fuente: Fotograma Blade Runner 2049

Otro color destacable en la cinta es el blanco, asociado con la verdad ( $c f$. en tabla 3). La habitación donde permanece recluida la hija de Deckard está pintada en este tono y su vestimenta coincide con esta gama cromática. Dicho tratamiento de color interviene en la significación de la obra, pues es a ella a quien busca K, es la clave de toda su investigación. Y hay algo llamativo en la composición de las imágenes que nos narran la trama entre K y la hija de Deckard, respecto al uso de este blanco: la primera vez que el protagonista habla con ella desconoce la verdad. Aquí observamos que él sale al exterior, a un lugar nevado en algunas zonas (figura 35); posteriormente, cuando K descubra el secreto, el mismo lugar estará cubierto por completo de nieve (figura 36). 
Figura 35. Salida de K, nieve parcial

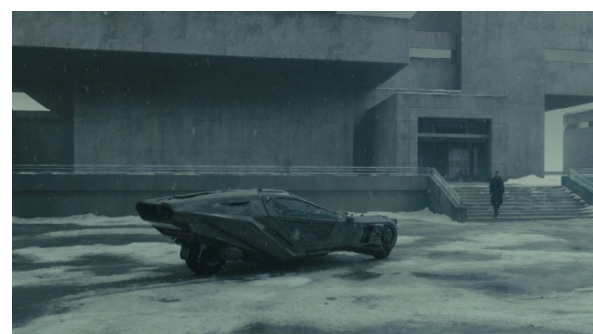

Fuente: Fotograma Blade Runner 2049
Figura 36. K descubre la verdad

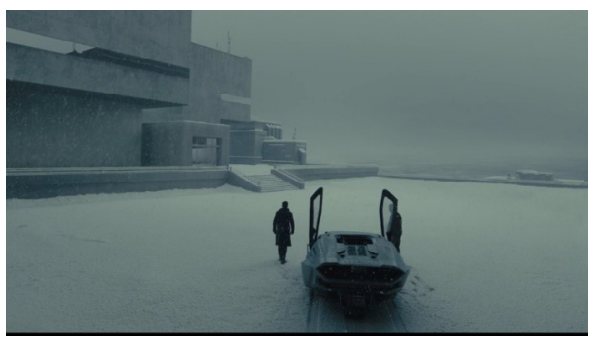

Fuente: Fotograma Blade Runner 2049

Finalmente, debemos hacer referencia a la presencia del color azul. En este caso, asociada con el cambio que experimentan los personajes al comenzar a vivir. Primero lo vemos con Joi (con vestido azul), que es un holograma y únicamente podía moverse por una habitación, pero logrará desplazarse con libertad gracias a la máquina adquirida por K (figura 37). De nuevo se emplea esta tonalidad cuando K descubre que no es el hijo de la replicante. Su imagen aparece impregnada con una luz magenta (figura 38), aunque al ayudar a Deckard y, con ello, tomar sus propias decisiones, por ende, vivir, escena en la que la iluminación que se cierne sobre él se tiñe de azul (figura 39).

Figura 37. Joi con vestido azul

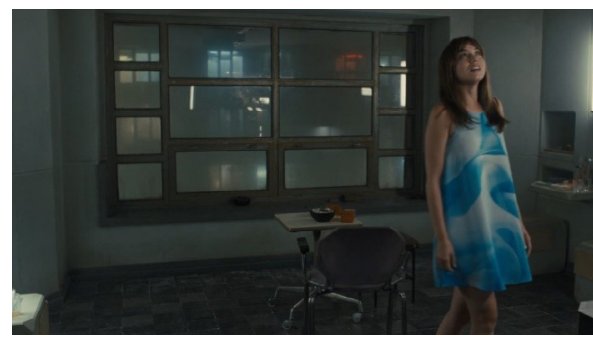

Fuente: Fotograma Blade Runner 2049
Figura 38. Imagen de $\mathrm{K}$ teñida en magenta

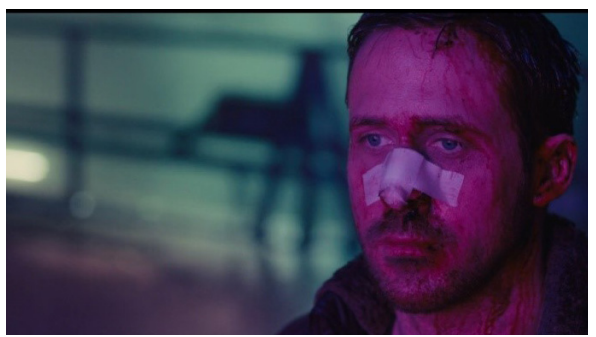

Fuente: Fotograma Blade Runner 2049

Figura 39. Imagen en azul: decisión de K

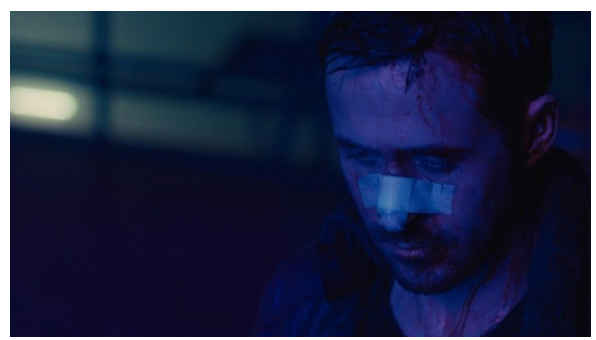

Fuente: Fotograma Blade Runner 2049 
Aquí se cierra el ciclo del protagonista. K ha tomado el mando y ha dejado de someterse a las órdenes de otros, ha renunciado a ser máquina para ser humano.

\subsubsection{La iluminación}

La iluminación en Blade Runner 2049 tiene un doble sentido: por un lado, al ser una película de ciencia ficción, su principal objetivo es el de conformar y hacer creíble la atmósfera futurista que presenta la historia. Por otro, aportará un significado dramático que enfatiza la intencionalidad de la luz, un ejemplo de ello es dotar a la ciudad de Los Ángeles, en la que se desarrolla la acción, de un valor deprimente y post apocalíptico, en consonancia a un espacio repleto de carteles de neón, signos antagónicos del ambiente oscuro en el que se encuentra y, al mismo tiempo, reflejo de la excesiva tecnologización de una decadente sociedad (figura 40), motivo por el cual además se emplean luces artificiales. Siguiendo la misma línea de este tratamiento de la luz como elemento expresivo, cabe citar diversas imágenes en las que aparece Wallace (Jared Leto), un personaje que representa al villano y que es mostrado preferentemente en penumbra e incluso en ocasiones, convertido en sombra o silueta (figura 41).

Figura 40. Ciudad futurista (L. A)

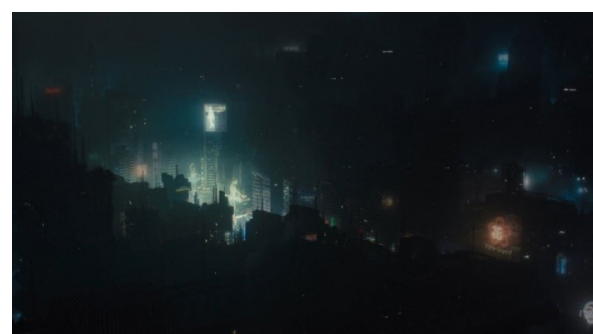

Fuente: Fotograma Blade Runner 2049
Figura 41. Wallace en penumbra

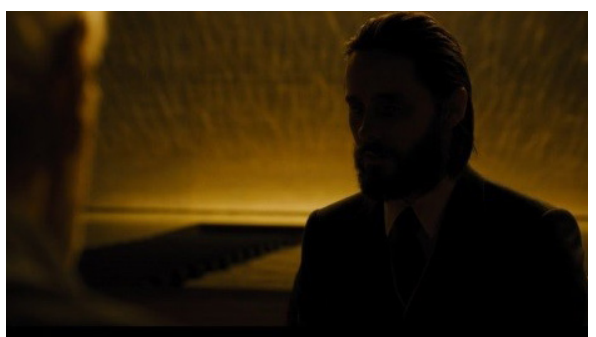

Fuente: Fotograma Blade Runner 2049

Observamos también el uso de la iluminación por manchas para iluminar las caras de los actores. Esto tiene una especial relevancia en la escena a la que hemos hecho referencia anteriormente que incide directamente sobre el protagonista, K, cuando toma las riendas de su vida, se arriesga a asumir sus propias decisiones como un ser humano. Esta iluminación por manchas destaca el cambio y la evolución final del personaje (revisar figuras 38 y 39). Además, el uso de los contraluces es bastante recurrente durante el film. Algunos ejemplos: K cree que es el niño que nació (confróntese en figura 33); K encuentra el paradero de Deckard (véase en figura 31).

Deakins trabaja con la luz para que intervenga en la historia, siendo parte activa de la acción, podría tratar a este elemento como a un personaje más. Aquí, es preciso poner en relieve la escena que recrea un concierto de Elvis, mediante un holograma, donde podemos ver la silueta de K a contraluz (figura 42) e inmediatamente después, mediante un juego de luces que se apagan y encienden en décimas de segundo, K desaparece por completo (figura 43). 


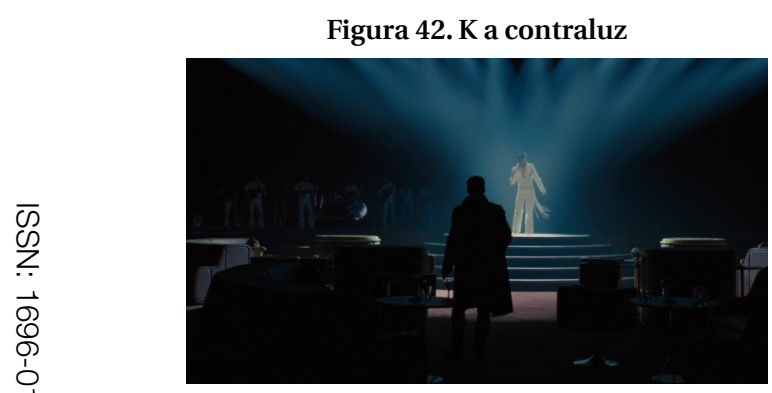

Fuente: Fotograma Blade Runner 2049
Figura 43. Ausencia de K

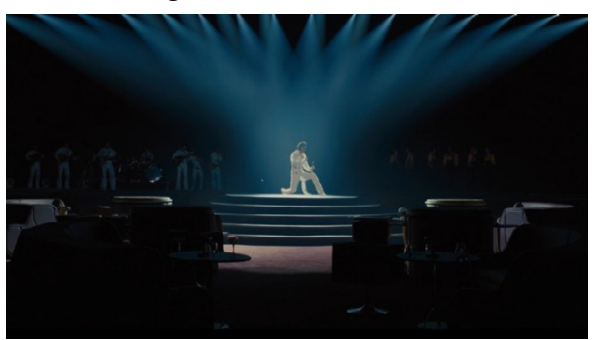

Fuente: Fotograma Blade Runner 2049

\section{Conclusiones y discusión}

A modo de conclusión, cabe decir que el análisis empírico de las imágenes de Fargo, El hombre que nunca estuvo allí, Sicario y Blade Runner 2049 nos ha permitido cumplir con el objetivo principal propuesto en la investigación, dado que el estudio de estos cuatro filmes se ha centrado en examinar la composición de imagen cinematográfica en la obra del camarógrafo Roger Deakins. Además, es posible afirmar que los objetivos específicos también se han alcanzado, pues hemos observado y examinado cómo el encuadre, la luz y el color son elementos expresivos de la construcción del relato cinematográfico creado por Deakins en estas películas seleccionadas.

Igualmente, se ha constatado que existen ciertas similitudes en los filmes: mayor empleo de los primeros planos (constatado en las gráficas 1, 3, 5 y 7) y dentro de la clasificación de primer plano, el más usado respecto a otros es el medio o busto (mostrado en las gráficas 2, 4, 6 y 8); intencionalidad en la aplicación de los colores (plasmado en el apartado de resultados), recurrencia de la iluminación por manchas, advirtiendo con ello una constante y frecuencia en el uso de estos recursos.

Asimismo, y en consecuencia a ello, hemos podido comprobar que la hipótesis planteada puede verificarse, pues se evidencia que la labor de dirección de fotografía de Roger Deakins es crucial para el significado de los filmes en los que interviene. Sí se concibe una finalidad semántica en su tarea como camarógrafo, lograda en las composiciones de imágenes que crea a partir de los recursos técnico-artísticos que emplea -encuadre, luz y color- que marcan expresivamente su obra. Es posible afirmar que la construcción creativa de las imágenes en las obras de Deakins, caracterizada por la recurrencia de algunos de estos elementos técnico-artísticos expresivos nos conduce a pensar que este director de fotografía ha adquirido a lo largo de su trayectoria un estilo propio. Diversos son los motivos que lo justifican. Atendiendo de nuevo a las variables, observamos que, en todas las cintas analizadas, como venimos diciendo, los encuadres predominantes son primeros planos (el más expresivo del lenguaje cinematográfico, logra guiar la mirada del espectador y destaca a los personajes). Puede acreditarse su frecuencia en las cuatro obras (las creadas por los hermanos Coen supera el $50 \%$ del total de los encuadres; en las realizadas por Villeneuve, su reiteración es un poco menor, pero sigue siendo el más empleado). El uso insistente de esta escala, concretamente el plano medio o busto, pone de manifiesto la intencionalidad del director. 
Con esta recurrencia, Deakins logra que el espectador indague en las entrañas de los personajes. En cuanto a la segunda unidad de análisis, el color, elemento enunciativo, corrobora sus connotaciones simbólicas, relacionadas con emociones, sensaciones o bien se asocia a personajes específicos o con momentos de la trama. Finalmente, respecto al manejo de la luz, apreciamos que los contraluces que se repiten para destacar personajes y crear siluetas, con el objetivo de potenciar las emociones (la iluminación por manchas). El empleo de la luz en la obra de Deakins aporta realismo al relato. Sin embargo, es significativo que en todos los títulos, además de utilizarse con una finalidad descriptiva, también exista una constante al aplica la luz por manchas, especialmente para reforzar el sentido dramático de la narración.

A lo largo de estas páginas hemos intentado reflexionar sobre el poder expresivo a través del ejercicio de dirección de fotografía en el oficio del cine, estudiando la obra de Roger Deakins, un arquitecto de la imagen, un artesano de la luz y referente en la profesión cinematográfica, cuya destreza en el manejo de las estructuras narrativas y dramáticas ha quedado evidenciada. Por todo ello, consideramos que es posible generar un debate futuro en torno a la mirada, el punto de vista de este cinematógrafo que nos invita a explorar en historias emocionales y por extensión sobre la condición humana, gracias a la composición de sus planos. Su trabajo apela, ciertamente, al análisis consciente.

\section{Referencias bibliográficas}

Andreu, J. y Pérez, A. (2006). Análisis de contenido cualitativo. En Revista de investigación aplicada social y política, № 1. Aronovich, R. (1997). Exponer una historia: la fotografía cinematográfica. Barcelona: Gedisa.

Brown, B. (2008). Cinematografía, teoría y práctica: la creación de imágenes para directores de fotografía, directores y operadores de vídeo. Barcelona: Omega.

Casasempere-Satorres, A. (2020). Análisis de datos con MAXQDA. Disponible en: https://n9.cl/hbhqh

Crespo, M. A. (2013). Dirección cinematográfica: manual avanzado de aprendizaje creativo. Córdoba: Autoedición.

Cortes-Selva, L. (2019). Tres décadas de estilo visual en el cine: Evolución de la fotografía cinematográfica (1980-2010). Barcelona: UOC.

Field, S. (1996). El manual del guionista: ejercicio e instrucciones para escribir un buen guión paso a paso. Madrid: Plot Ediciones.

Gómez-Diago, G. (2010). Triangulación metodológica: paradigma para investigar desde la ciencia de la comunicación. En Razón y Palabra, № 72.

Guerín, M. A. (2004). El relato cinematográfico. Sin relato no hay cine, Barcelona: Paidós.

Gutiérrez San Miguel, B. (2006). Teoría de la narración audiovisual. Madrid: Cátedra.

- (2020). En Miguel-Borrás, M. y Cea-Navas, A. I. (eds.), El cortometraje. Valoración y grandeza del formato. Valencia: Tirant lo Blanch, Tirant Humanidades.

Heller, E. (2008). Psicología del color: cómo actúan los colores sobre los sentimientos y la razón. Barcelona: Gustavo Gili, S.L. Hernández-Sampieri, R. (2014). Metodología de la investigación. México: McGraw-Hill. 
Llinás, F. (1989). Directores de fotografía del cine español. Madrid: Filmoteca Española, Instituto de la Cinematografía y de las Artes Audiovisuales, Ministerio de Cultura.

Mascelli, J. V. (1965). The Fice C's of cinematography. Motion picture filming techniques. Los Angeles: Silman James Press. Romaguera, J. y Alsina, H. (1989). Textos y manifiestos del Cine, Madrid: Cátedra.

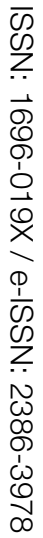

Salt, B. (2006). Moving into Pictures. Londres: Starword.

Santos-Aparicio, A. (2019). Tiempos de ninguna edad. Madrid: Cátedra.

Tolan, G. (1941). El cameraman cinematográfico. En Theater Arts, Nueva York. 